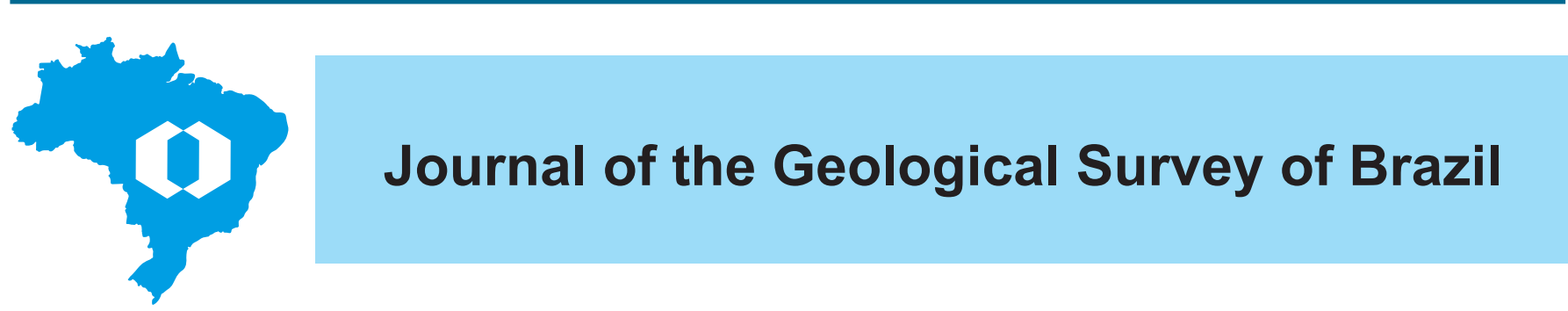

\title{
The strategic diagnosis of the potassium fertilizer industry in Brazil
}

\author{
Pedro Igor Veillard Farias ${ }^{1,2}$, Estevão Freire ${ }^{1}$, Armando Lucas Cherem da Cunha', \\ Adelaide Maria de Souza Antunes ${ }^{1,2}$ \\ ${ }^{1}$ Escola de Química, Universidade Federal do Rio de Janeiro (UFRJ), Rio de Janeiro-RJ, Brazil, CEP: 21949-900 \\ ${ }^{2}$ Instituto Nacional de Propriedade Industrial (INPI), Rio de Janeiro-RJ, Brazil, CEP: 20090-910
}

\section{Abstract}

Fertilizers and crop nutrition play a key role in fulfilling the United Nations Sustainable Development Agenda. Brazil is the world's fourth largest consumer of fertilizers. Between 1998 and 2018, the apparent consumption of potash fertilizers (in terms of $\mathrm{K}_{2} \mathrm{O}$ content) almost tripled, while the production of potassium chloride decreased in Brazil. Two important projects (Carnalita and Autazes) are still in the design phase, and there is considerable uncertainty surrounding them. Potassium producers located in Canada, Russia and Belarus have competitive advantages when compared to Brazil. The aim of this paper is to make a strategic diagnosis of the potassium fertilizer industry. The major variables that characterize the status of the Brazilian fertilizer industry could be identified, on the basis of data collected from annual business reports, reports from consulting firms, government websites, books, newspaper articles, sectoral studies and scientific articles. This paper concluded that, after detection of the current fragility of this sector, which is essential to the agribusiness production chain, public policies have to be formulated with a view to boosting this industry, based on the competitive advantages related to proximity to the Brazilian consumer market. However, there are disadvantages, namely, access to raw material, the need for infrastructure development and entry barriers caused by factors of scale and idle installed capacity in the major global players.
Article Information

Publication type: Research papers

Received 12 February 2021

Accepted 28 June 2021

Online pub. 11 August 2021

Editor: E.L. Klein

\section{Keywords:}

Potassium fertilizers,

mineral economy,

diagnosis of the mineral sector

agrominerals

${ }^{*}$ Corresponding author

Pedro Igor Veillard Farias

E-mail address: pedro.veillard@eq.ufrj.br

\section{Introduction}

Fertilizers are essential chemical compounds for agricultural activity (IFDC and UNIDO 1998; Lapido-Loureiro et al. 2008; IFA 2020a). Fertilizers and crop nutrition play a key role in achieving Goal 2 of the United Nations Sustainable Development Agenda (Zero Hunger and Sustainable Agriculture), as they contribute $50 \%$ of the world's food production (IFA 2020a; United Nations 2020). Furthermore, fertilizers can increase $\mathrm{CO}_{2}$ sequestration in the soil increasing biomass yield (Hijbeek et al. 2019) and avoiding the expansion of the planted area (Burney et al. 2010; IFA 2020a).

Brazil is the world's fourth largest consumer of fertilizers, but its imports - as a percentage of its total consumption of NPK - have increased from 32\% in 1988 to over $80 \%$ in 2019 (Farias et al. 2020). Between 1998 and 2018, the apparent consumption of potassium fertilizers increased (in terms of $\mathrm{K}_{2} \mathrm{O}$ content) by more than $250 \%$ in Brazil. However, in the same period, the production of potassium chloride (the main potash fertilizer in Brazil) remained stable, with a downward trend over the last 10 years (CETEM 2020). In 2019, NPK imports exceeded 9 billion dollars. Out of these 9 billion, approximately 3.5 billion referred to imports of potassium fertilizers (COMEXTAT 2020).

Potassium is involved in several metabolic processes. In plants, it is involved in enzymatic activation, osmotic control of water balance, and production and breakdown of carbohydrates (Nascimento and Lapido-Loureiro 2004). Potassium-deficient plants have reduced ability to use soil water, which decreases their ability to absorb other nutrients. Potassium is known as a quality nutrient, owing to its influence on macroscopic aspects of plants, such as size, shape, color and flavor. (Gomes et al. 2008).

This paper aims to make a strategic diagnosis of the Brazilian potash industry to check for possible threats and opportunities regarding the production chain of this essential input to the Brazilian agricultural activity, in order to provide public policy makers with valuable information. The points discussed in this diagnosis will serve as a source of information for the construction of prospective scenarios for this industry 
in further research. Prospective scenarios are combinations of discrete variables, called events, which describe several possible futures. Each event transforms a strategic issue into a discrete variable as a function of the organization's strategic decision-making values (Grumbach et al. 2020). In this context, to explore and characterize the major variables that compose the Brazilian potash fertilizer industry, a strategic diagnosis needs to be made of the system in question.

\section{Method}

Underpinned in the specific literature on the construction of strategic diagnoses (Porter 1998; Bain and Company 2014; Bain and Company and Gas Energy 2015; Grumbach et al. 2020; Marcial and Grumbach 2008), this analysis deals with issues regarding: companies that make up the sector - market structure; in-depth description of production at the location/ company/factory level; profile of organizations; economic situation of organizations; scale of plants and investments required for expansion of production; domestic market and foreign trade; access to raw materials; level of technology mastery. For comparative purposes, this diagnosis also addresses some topics relative to this industrial sector in a global context. Such information was collected from annual business reports, reports from consulting firms, government websites, books, newspaper articles, sectoral studies, scientific articles, etc. Variables were explored if their respective future behavior was likely to favorably or unfavorably affect the Brazilian industry of potassium fertilizers somehow. Moreover, this diagnosis prioritized variables internal to the Brazilian potash fertilizer industry, preferably the ones related to production factors and the strategy/structure/rivalry of companies.

\section{Results and Discussion}

\subsection{Companies that make up the sector: market structure}

Between 1998 and 2018, the apparent consumption of potassium fertilizers (in terms of $\mathrm{K}_{2} \mathrm{O}$ content) almost tripled. However, in the same period, the production of potassium chloride (the main potash fertilizer in Brazil) remained stable, with incremental decreases (ANDA 2019; CETEM 2020).

The main indicator to evaluate the production of potash fertilizers in Brazil is the production of $\mathrm{KCl}$ (potassium chloride). In 2018, 343,996 tons of $\mathrm{KCl}$ were produced in Brazil, an amount equivalent to 199,521 tons in terms of $\mathrm{K}_{2} \mathrm{O}$ (Figure 1). All this production is destined for the fertilizer industry. Furthermore, in recent years, the production of $\mathrm{KCl}$ in Brazil has remained below installed capacity and far below apparent consumption (deliveries made to the agricultural market). Figure 1 shows the decrease in $\mathrm{KCl}$ production by about $30 \%$, when comparing the results of 2018 to those of 2017.

A comparison of the production capacity of potassium chloride in Brazil with the quantity delivered in Brazil (apparent consumption), it can be seen that the Brazilian production barely meets the demand for potash fertilizers, which creates a demand for imported potassium fertilizers. If it operated at full productive capacity, the Brazilian industry would have been able to meet only $6.3 \%$ of the national demand in 2018 (ANDA 2019). Imported potassium fertilizers occupy an important portion of the Brazilian market share; they account for almost all apparent consumption in Brazil (Table 1). In view of the small amount of players (only one: Mosaic Fertilizantes P\&K) and the high share of demand met by imports (as with nitrogen

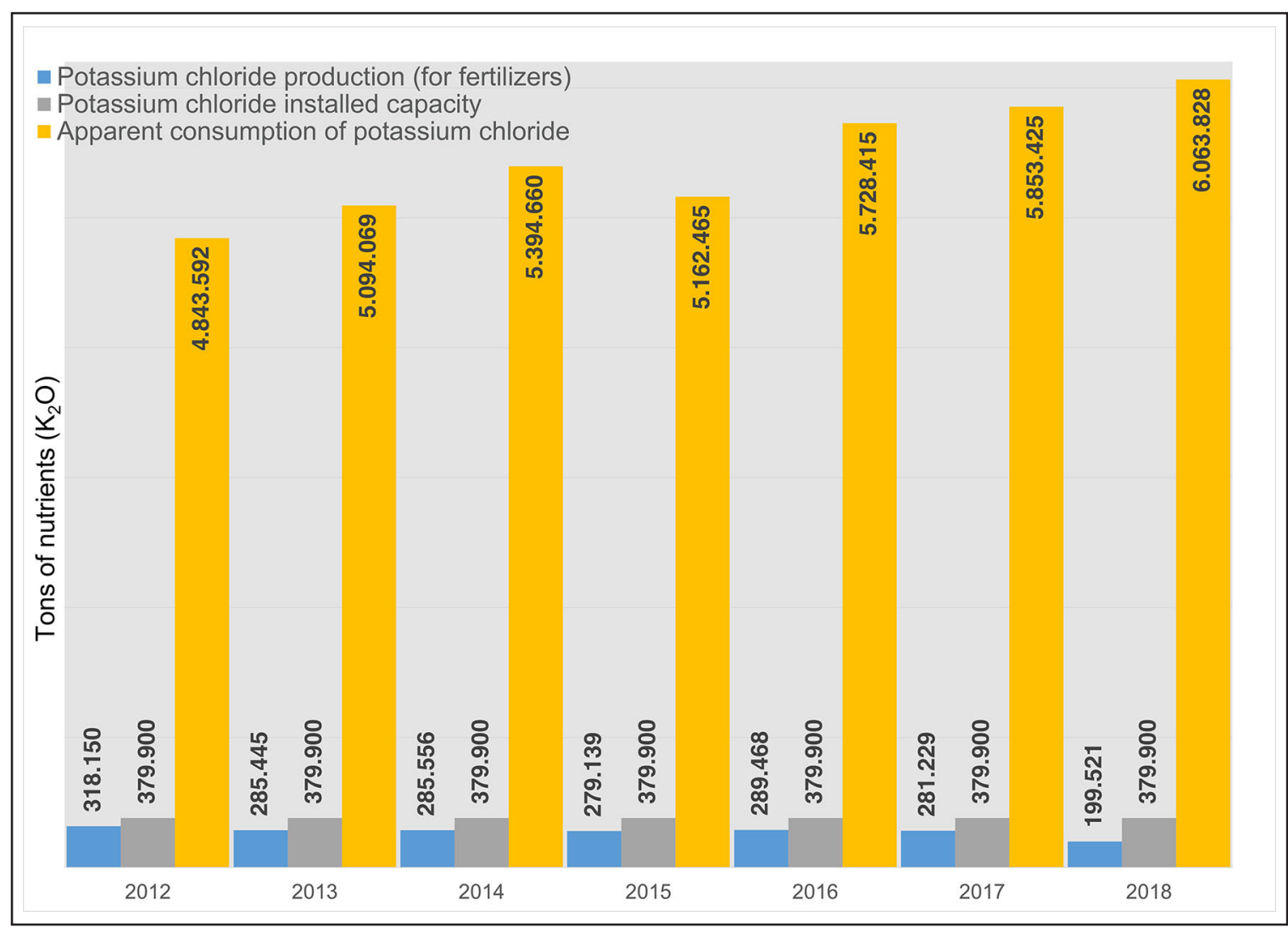

FIGURE 1. Production (for fertilizers), installed capacity and apparent consumption of potassium chloride. Source: ANDA (2019). 
fertilizers), there was no need to characterize the structure of the industry according to the market shares dominated by the four major companies (the CR4 Index) or according to the $\mathrm{HHI}$ Index (the Herfindal-Hirschman Index).

\subsection{In-depth description of production at the location/ company/factory level}

In 2018 (Table 2), 343,996 tons of potassium chloride were produced in Brazil, an amount equivalent to 199,521 tons of potassium chloride (in terms of $\mathrm{K}_{2} \mathrm{O}$ content). Over the past few years, the North/Northeast region was responsible for $100 \%$ of the Brazilian production of potassium chloride. The Taquari-Vassouras (Sergipe) mine, the only producer of potassium chloride in Brazil, was acquired on January 18, 2018 by Mosaic P\&K. Previously, it was an asset of Vale Fertilizantes S.A. (Mosaic 2016; Vale 2019).

\subsection{Profile (history, business, mission, vision, values,} critical success factors, policies) and Economic Situation of Organizations

\subsubsection{Mosaic}

Mosaic Company maintains its potash production distributed into two segments of the company - in the Potassium business segment and in the "Mosaic Fertilizantes P\&K" business segment. Mosaic, in the Potassium business segment, operates three mines in Canada (two shaft mines and one dissolution mine) and a shaft mine in the US. Each of these mines has the facilities required to process the mined potash ore. The company also has an ongoing project in Kronau (Saskatchewan, Canada), acquired from Vale Fertilizantes. Currently, Mosaic (in the US and Canada) has an installed capacity of 10.5 million tons per year for potash. This value is equivalent to $12 \%$ of the installed capacity in the world (Mosaic 2019c).

The Mosaic Fertilizantes P\&K business segment operates mines, chemical plants, formulation and distribution facilities for formulated NPK fertilizers, ports and warehouses in Brazil and Paraguay. Potash production occurs exclusively at the Taquari-Vassouras mine, located in Rosário do Catete (State of Sergipe). Production and sales of potash are targeted at the Brazilian domestic market. Underground mining takes place in an area that crosses the boundary of three municipalities: Rosário do Catete, Carmópolis and Capela, all in Sergipe. The mined ore, sylvinite (combination of halite and sylvite, or sodium chloride and potassium chloride), is mined at a depth of 500 to 740 meters. Mining in these locations uses the method of chambers and pillars. Processing, which also takes place at the unit, consists of the phases of crushing, concentration, dissolution, drying, compaction and distribution storage. The unit's reported operational capacity is the production of 520,000 tons of product per year and, in 2018, 345,000 tons of potassium chloride (with $\mathrm{K}_{2} \mathrm{O}$ content of $58 \%$ ) were produced. This amount represents $100 \%$ of Brazilian production. In such unit, the company uses Petrobras's mining rights and pays royalties to them on an annual basis. Mosaic argues that one the main risks associated with its businesses, as mentioned above (that is, conditions that indirectly delimit its critical success factors), is the occurrence of brine inflow at the Esterhazy mine in Canada, which has been in operation since 1985. It also highlights that such an effect can occur in other mines. This effect, mitigated by artificially pumping out such brine (which penetrates the mining area), can affect the mine's production and even bring it to a halt (Mosaic 2019c).

Mosaic sold about $\$ 9.6$ billion worth in products and services in 2018. The company's net income in 2018 was $\$ 470.0$ million (or $\$ 1.22$ per diluted share), compared to a loss of $\$ 107$ million in 2017 and a profit of \$297.8 million in 2016 . In 2018 , the Potassium business segment was responsible for $32 \%$ of sales (in tons), $23 \%$ of revenue and $49 \%$ of operating profits. The Mosaic Fertilizantes P\&K segment (which covers operations in South America, not only for potash) was responsible for $33 \%$ of sales (in tons), $39 \%$ of revenue and $24 \%$ of operating profits (Mosaic 2019c). In the Potassium segment (Mosaic 2019c), sales increased from 8.6 million tons (in 2017) to 8.8 million tons (in 2018), boosted by strong demand. The gross margin of the Potassium segment was US\$ 597.2 million in 2018, an amount 260.2 million dollars higher than in 2017, especially because of an increase in potassium chloride prices in the foreign market (in 2018, the company's selling price was $\$ 248$ dollars per ton, a value higher than that of the previous year by 33 dollars per ton). In the Mosaic Fertilizantes P\&K segment (which includes

TABLE 1. Fertilizer balance (in terms of $\mathrm{K}_{2} \mathrm{O}$ content) in Brazil - Source: ANDA (2019).

\begin{tabular}{|c|c|c|c|c|c|c|c|}
\hline \multirow{2}{*}{ Balanço } & \multicolumn{7}{|c|}{ Contained $\mathrm{K}_{2} \mathrm{O}$ (1000 Tons) } \\
\hline & 2012 & 2013 & 2014 & 2015 & 2016 & 2017 & 2018 \\
\hline Production & 318 & 285 & 286 & 279 & 289 & 281 & 199 \\
\hline Exports & -62 & -85 & -87 & -70 & -69 & -40 & -37 \\
\hline delivery (aparent consumption) & 4844 & 5094 & 5395 & 5162 & 5728 & 5853 & 6064 \\
\hline
\end{tabular}

TABLE 2. Potassium production in Brazil - Source: ANDA (2013, 2014, 2015, 2016, 2017, 2018, 2019).

\begin{tabular}{|c|c|c|c|c|c|c|}
\hline \multicolumn{7}{|c|}{ KCI Production (Tons) } \\
\hline 2012 & 2013 & 2014 & 2015 & 2016 & 2017 & 2018 \\
\hline 548,533 & 492,152 & 492,355 & 481,269 & 499,082 & 484,877 & 343,996 \\
\hline \multicolumn{7}{|c|}{$\mathrm{KCI}$ Production (Tons of $\mathrm{K}_{2} \mathrm{O}$ ) } \\
\hline 2012 & 2013 & 2014 & 2015 & 2016 & 2017 & 2018 \\
\hline 318,150 & 285,445 & 285,556 & 279,139 & 289,468 & 281,229 & 199,521 \\
\hline
\end{tabular}


operations in South America - not only for potash), gross sales were US\$ 3.7 billion in 2018, compared to US\$ 2.2 billion in 2017 and US $\$ 2.1$ billion in 2016 . The evolution of this revenue was caused by the increase in sales of conventional and premium fertilizers (also driven by the market share acquired by Mosaic) and by the price increase in the international market. While 6 million tons of fertilizers were sold in 2017, 9.1 million tons were sold in 2018. The gross profit margin achieved in 2018 was US $\$ 382.9$ million. Particularly regarding potash, in the Mosaic Fertilizantes P\&K segment, the sale of products from the Taquari-Vassouras mine was 323,000 tons in 2018 (a value below that of 2017 , owing to operational failures). Mosaic has not informed the financial value of this transaction, as the company is vertically integrated and formulates this nutrient (along with phosphate and nitrogen fertilizers) for distribution and sale. However, Mosaic has reported the sale of 323.00 tons of potash produced in Brazil, 2,847,000 tons of phosphate produced in Brazil and 5,964,000 tons of imported nutrients (i.e., a total of $9,134,000$ tons) was carried out at US $\$ 410$ by ton (Mosaic 2019c).

\subsubsection{Potássio do Brasil (Brazil Potash)}

Potássio do Brasil is a fertilizer company whose goal is to extract potassium salts in Autazes, in the state of Amazonas. Founded in 2009, it is a Brazilian, privately held company, controlled by Brazilian and foreign investors. In 2010, it received authorization to start drilling in Amazonas (Potássio do Brasil 2015b). In 2013, it began environmental studies for further implementation of the project; in 2014, it submitted the final mineral research report to the National Department of Mineral Production - DNPM (currently known as the National Mining Agency - ANM). In 2015, it received the approval of DNPM and the preliminary license from the Environmental Protection Agency of Amazonas (IPAAM) (Potássio do Brasil 2016). In 2016, the technical and economic feasibility study of the project was completed. By 2017, more than 180 million dollars had been invested in the development of the project and, an investment of another 2 billion dollars is expected by the end of construction (Potássio do Brasil 2018).

The company highlights the following success factors of the project: (1) Brazil is the world's largest exporter of agricultural products, that is, one of the most important markets for fertilizers in the world, and it currently imports around 94\% of the potash required for this sector; (2) the main potash suppliers to Brazil are currently at a distance that ranges between 14,000 and 20,000 kilometers; (3) the Autazes project is located just eight kilometers from a very navigable system, a river with access to areas of agricultural activity, especially MATOPIBA (Maranhão, Tocantins, Piauí and Bahia) and the Cerrado; (4) there is no prospect of creating a replacement for potassium as a nutrient in agricultural crops; (5) potassium chloride, among basic agricultural fertilizers, often has the highest price on the international market; (6) Brazil will have potash available at a lower cost, as the cost of transportation associated with importing potash from abroad often amounts to US\$133 per ton, while the average domestic transportation is estimated at US\$53 per ton (Potássio do Brasil 2018).

\subsection{Domestic Market and Foreign Trade}

Based on data from the Brazilian National Fertilizer Association (ANDA) (2019), of all fertilizers delivered to the final consumer in Brazil (apparent consumption) in 2018 (35.506 million tons), approximately $17.1 \%$ (6,064 tons) refers to potassium content $\left(\mathrm{K}_{2} \mathrm{O}\right)$.

From the perspective of access to the final consumer (Figures 2 and 3), and more particularly for potassium chloride $(\mathrm{KCl})$, the only producing region (North/Northeast Region) was responsible for the production of 343,996 tons of sodium chloride (a value equivalent to 199,521 tons of $\mathrm{K}_{2} \mathrm{O}$ ). In the same region, 854,428 tons of potassium fertilizers were delivered in terms of $\mathrm{K}_{2} \mathrm{O}$ content, Thus, it can be concluded that, even though it is the only region in Brazil that produces potassium chloride, the North/Northeast Region showed a deficit of 654,907 tons of $\mathrm{K}_{2} \mathrm{O}$ in 2018 . Of the quantity delivered in the North/Northeast Region (apparent consumption), 95.4\% is formulated in the region itself (ANDA 2019). Therefore, it can be inferred that, if potash production were expanded in the North/Northeast Region, it could be absorbed in the regional agricultural market itself (considering the year 2018).

In the Southeast Region, apparent consumption was $1,187,756$ tons of $\mathrm{K}_{2} \mathrm{O}$, and $1,139,690(96.0 \%)$ comes from formulators / distributors in the region. Therefore, it can be inferred that, if production of potassium were expanded in the Southeast Region (reaching the maximum value of 1,139,690 tons of $\mathrm{K}_{2} \mathrm{O}$ ), it could be absorbed in the regional agricultural market itself (considering the year 2018). In the South Region, apparent consumption was $1,728,794$ tons of $\mathrm{K}_{2} \mathrm{O}$, and $1,705,544(98.7 \%)$ comes from formulators / distributors in the region. Thus, it can also be inferred that if production of potassium were expanded in the Southeast Region (reaching

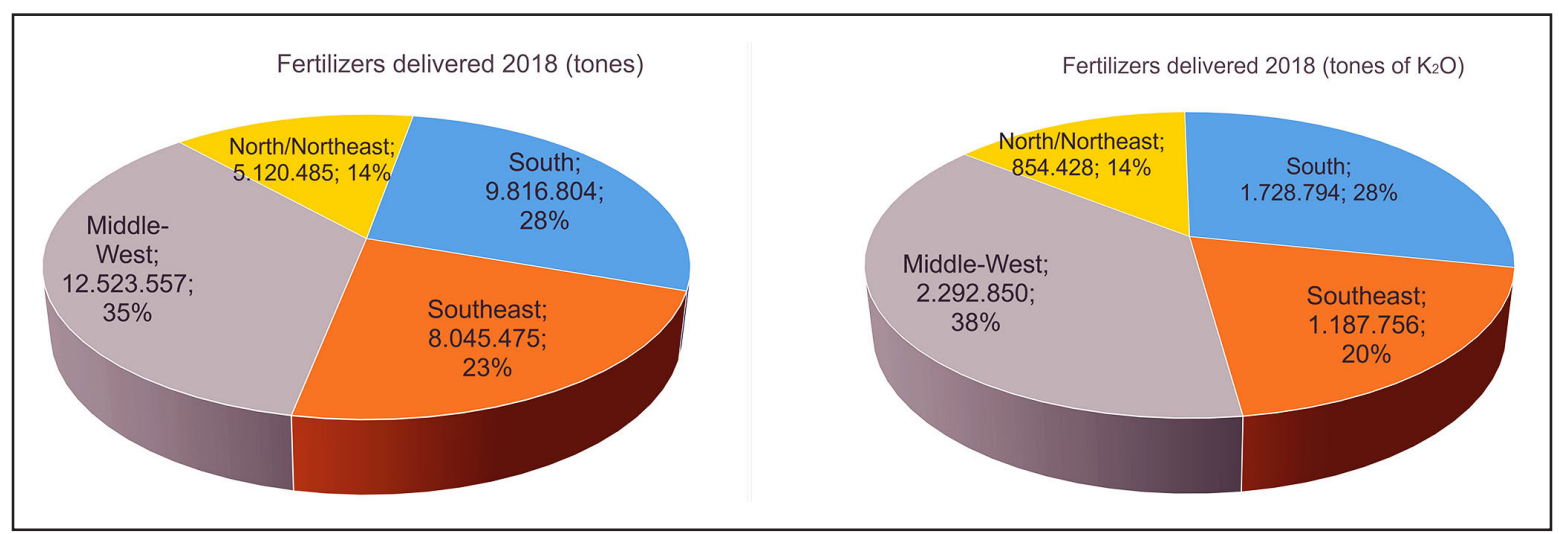

FIGURE 2. Fertilizer delivery (overall total and total in $\mathrm{K}_{2} \mathrm{O}$ ) by region (ANDA 2019). 


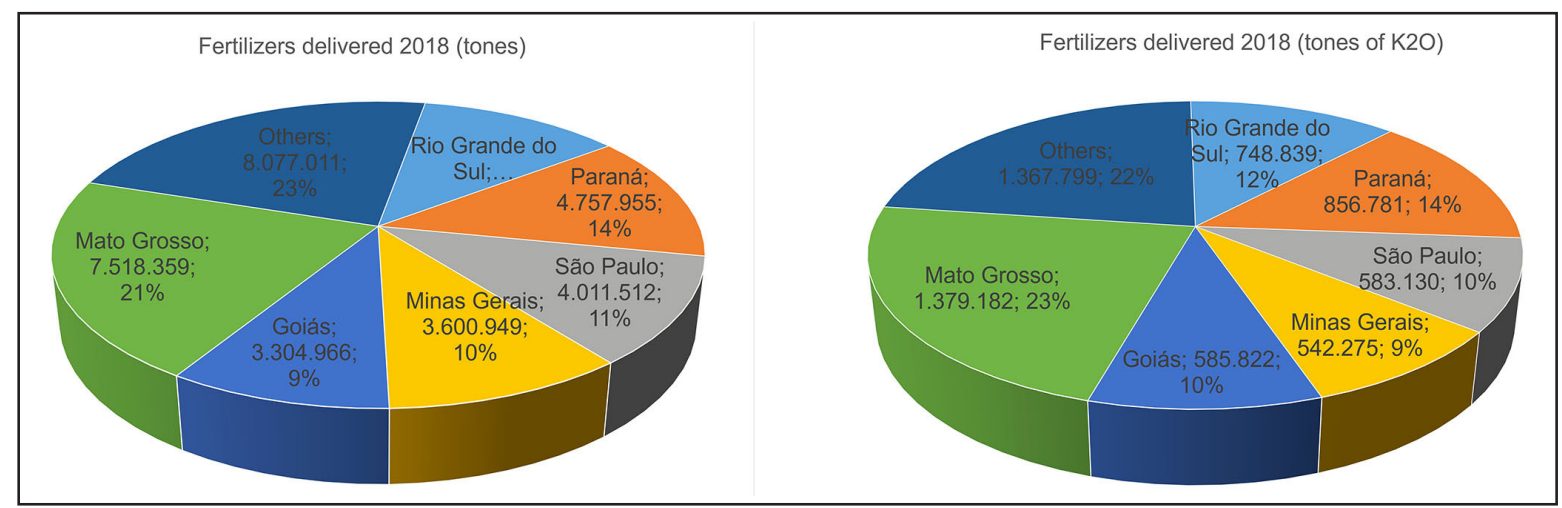

FIGURE 3. Fertilizer delivery (overall total and total in $\mathrm{K}_{2} \mathrm{O}$ ) by state (ANDA 2019).

the maximum value of $1,705,544$ tons of $\mathrm{K}_{2} \mathrm{O}$ ), it could be absorbed in the regional agricultural market itself (considering the year 2018). In the Midwest Region, apparent consumption was $2,292,850$ tons of $\mathrm{K}_{2} \mathrm{O}$, and 1,797,204 (78.4\%) comes from formulators / distributors in the region. This way, it can also be inferred that if production of potassium were expanded in the Midwest (reaching the maximum value of 1,705,204 tons of $\mathrm{K}_{2} \mathrm{O}$ ), it could be absorbed in the regional agricultural market itself (considering the year 2018).

As with global consumption of nitrogen and phosphate by region, East Asia is the world's largest consumer of potassium fertilizers. Consumption is driven by the Chinese market. South Asia is the second largest consumer market, mostly driven by India. The North American consumption is mainly driven by the USA. Latin American consumption is mainly driven by the Brazilian market (ANDA 2019; IFA 2020b).

Brazil is currently the largest potash importer in the world, followed by the US and China. The main countries that supply the market are Canada, Belarus and Russia. Canada, the world's largest potash exporter, supplies markets in Brazil, China, South Korea, the USA (the main destination for Canadian potash), India, Indonesia, Japan and Malaysia (ICIS 2018; ANDA 2019; IFA 2020b).

Potassium chloride is the fertilizer that faces the largest gap in the Brazilian fertilizer industry. Brazil imported around 10.7 million tons in 2019 (a value equivalent to US\$ 3.5 billion). Imports of "Other Potassium Chloride - NCM 31042090" were predominant $(96.4 \%$ of the total value) (COMEXTAT 2020). Major exporters (Figure 4) to Brazil in the year 2019 were Canada (33\%, in tons), Russia (28\%), Belarus (16\%), Germany $(10 \%)$ and Israel (9\%). Such imports occurred mainly (Figure 5 ) through the Ports of Paranaguá (26\%), Santos (22\%), Rio Grande (15\%), Vitória (7\%) and São Luís (7\%).

$\mathrm{KCl}$ (other potassium chloride, NCM 31042090) from Canada was purchased at an average price of US\$FOB $331.48 /$ ton in 2019. In the same year, Russia exported at a price of US\$FOB 322.54/ton, Belarus exported at US\$ FOB $324.44 /$ ton and Germany at US\$ FOB 333.48/ton (Figure 6).

\subsection{Scale of Plants, Investments Required for Produc- tion Expansion, Access to Raw Materials}

In 2018, 42 million tons of potassium chloride were produced in the world $\left(\mathrm{K}_{2} \mathrm{O}\right.$ content). Potassium chloride production increased at an average annual rate of $3.61 \%$ per year between 1998 and 2007 and at an average annual rate

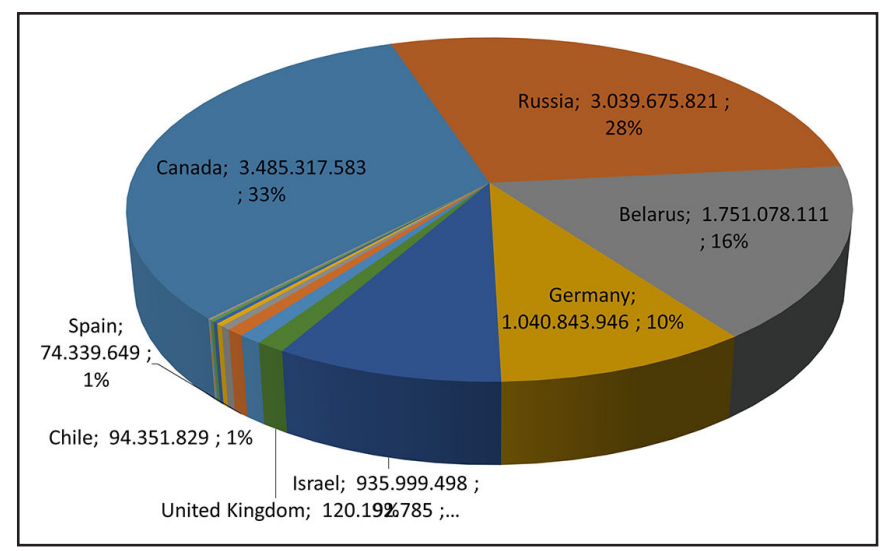

FIGURE 4. Imports of phosphate fertilizers (SH4-3104) in Brazil in 2019, by country and in $\mathrm{Kg}$ (COMEXTAT 2020).

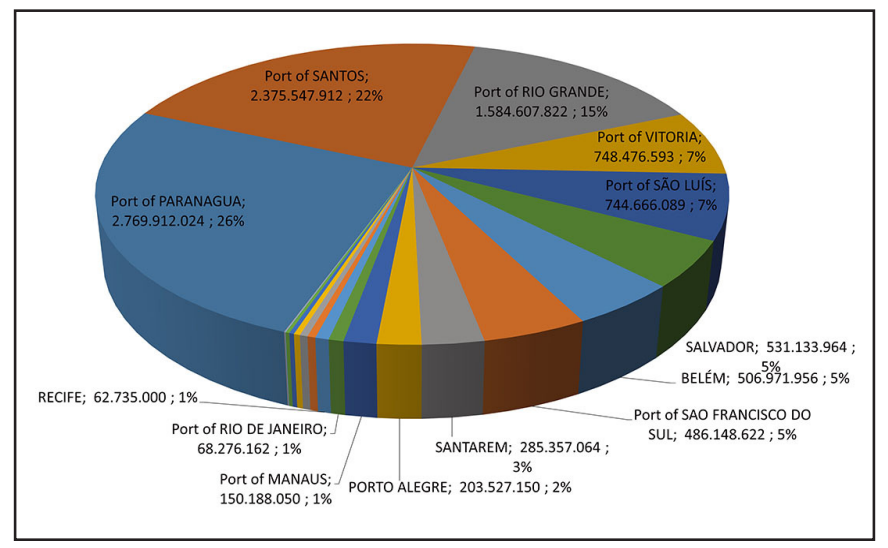

FIGURE 5. Imports of potassium fertilizers (SH4-3104) in Brazil in 2019, by accountable URF (Federal Revenue Unit) and in Kg (COMEXTAT 2020).

of $2.08 \%$ per year between 2008 and 2017 (Figure 7). Canada is the world leader in potash production, followed by Russia, Belarus, China and Germany (Figure 8).

The world's main potash producers (Canada, Russia, Belarus, China, Germany and Israel) stand out in terms of mineral reserves. Canada, which produced 12 million tons of $\mathrm{K}_{2} \mathrm{O}$ in 2018 , has $20.69 \%$ of the world's recoverable reserves. Russia (production of 7.5 million tons of $\mathrm{K}_{2} \mathrm{O}$ in 2018) and Belarus hold, respectively, $34.48 \%$ and $12.93 \%$ of the world's recoverable reserves. Brazil has only $0.41 \%$ of the world's reserves - 24 million tons (USGS 2019). 


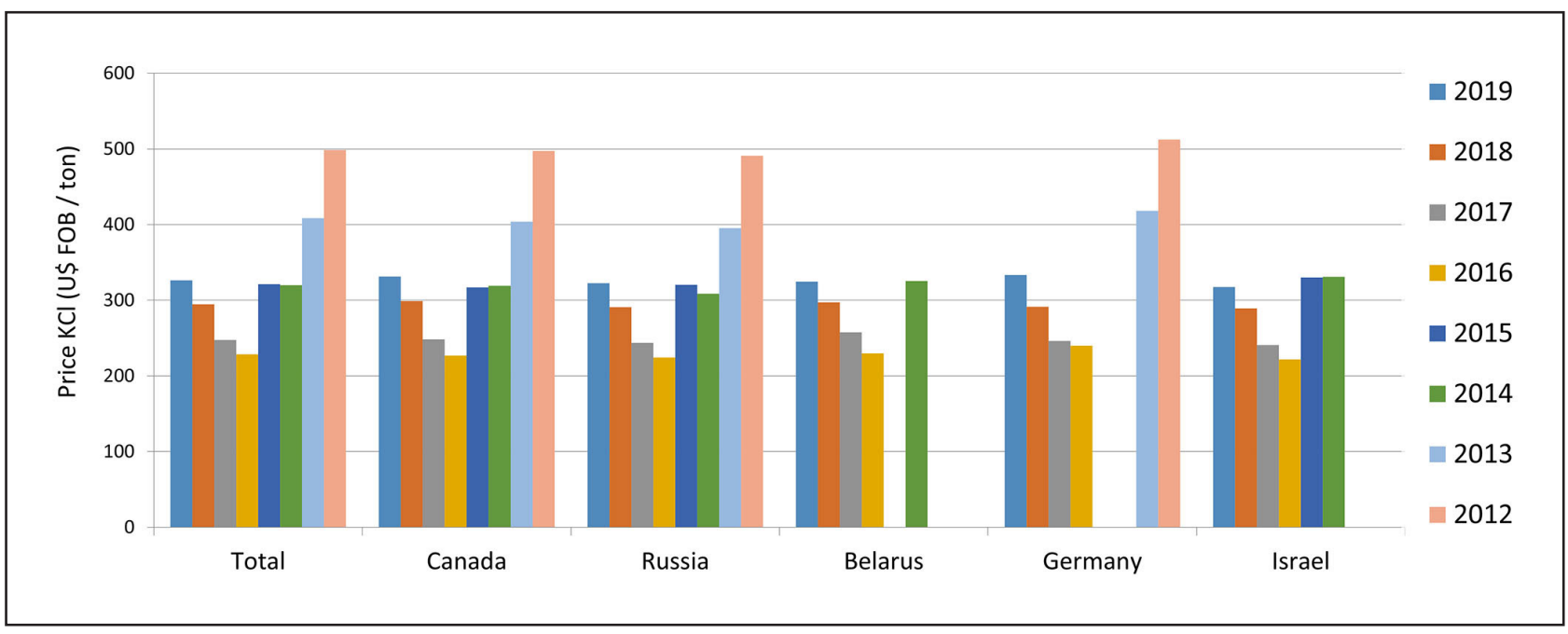

FIGURE 6. KCl import price, by country, from 2012 to 2019 (COMEXTAT 2020).

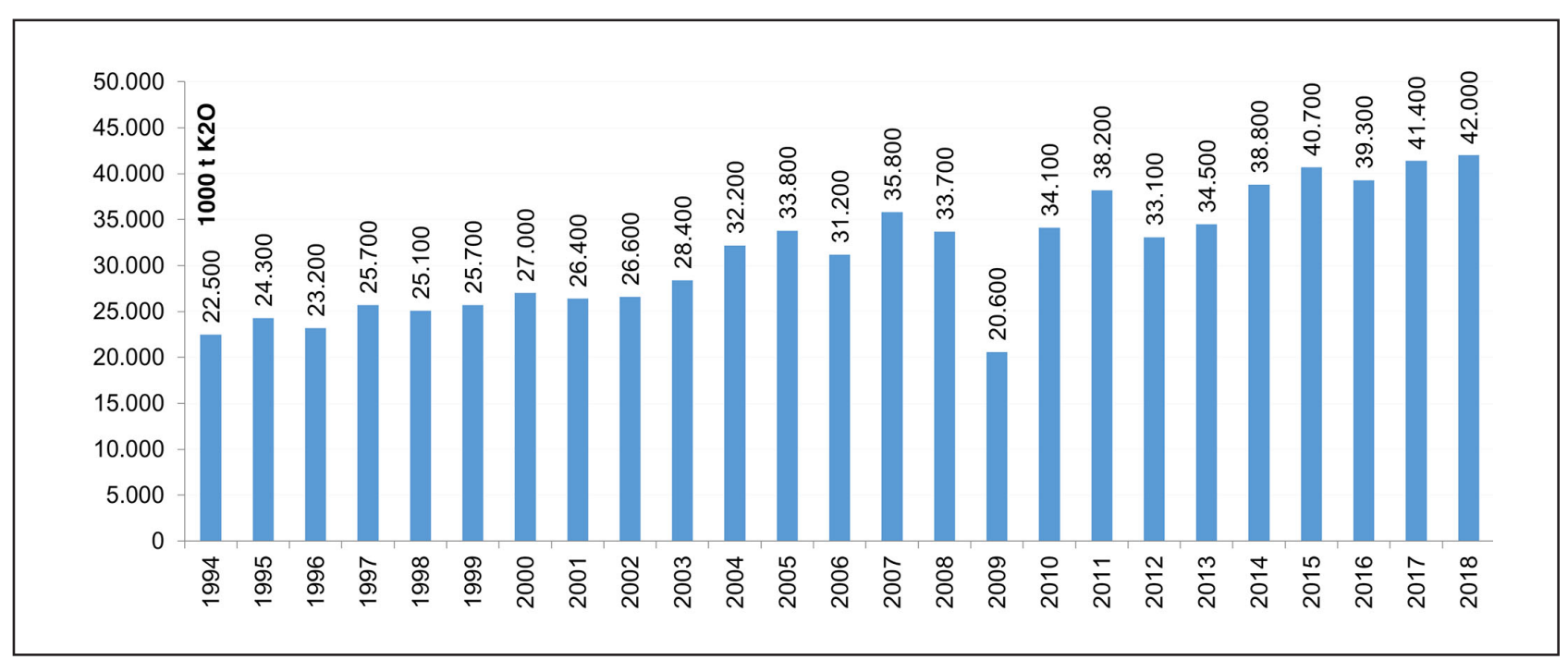

FIGURE 7. World production of phosphate rock between 1993 and 2018 (USGS 2019).

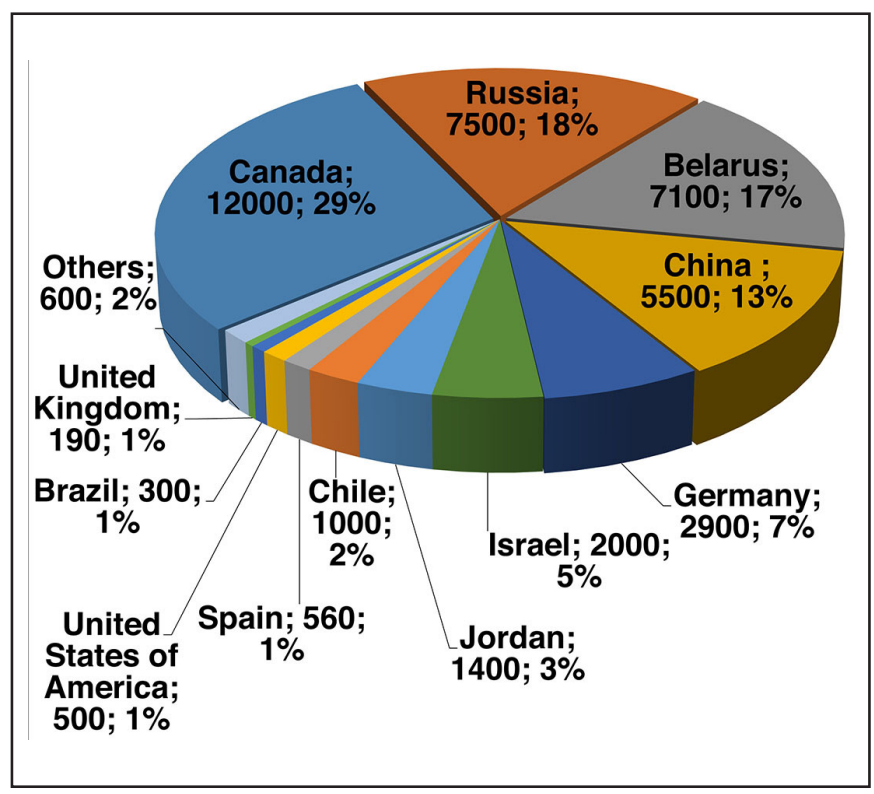

FIGURE 8 . $\mathrm{KCl}$ production (in $1000 \mathrm{t}_{\text {of }} \mathrm{K}_{2} \mathrm{O}$ ) in 2018 , by country and respective percentage of global production (USGS 2019)

\subsubsection{Brazil}

In Brazil, the only active producer of potassium chloride (the Taquari-Vassouras mine, belonging to Mosaic Fertilizantes P\&K) has an installed capacity of 379,900 tons of $\mathrm{K}_{2} \mathrm{O}$ (ANDA 2019). Also in Brazil, there are two large investments that have been announced a few years ago: the Carnalita Project and the Autazes Project.

The Carnalita Project, conceived at the time by Vale Fertilizantes, aims to explore carnallite in the city of Capela (Sergipe). The mining process is planned to use the dissolution method, and production was expected to start in 2016, but it has not occurred so far. Production is estimated at 1.2 million tons of $\mathrm{KCl} /$ year, equivalent to 700,000 tons of $\mathrm{K}_{2} \mathrm{O}$. Useful life of production assets is estimated at 40 years (DNPM 2015). Vale, in a presentation to the Brazilian Federal Senate, reported that the CAPEX investment in the project is $R \$ 4$ billion. There have been studies on the possibility of expanding investment and production. During the operation phase, 1000 direct jobs and 2750 indirect jobs are expected to be created. A total of 44 kilometers of brine pipelines and water mains will be built, 604 wells will be drilled and 330 tons of steam per 
hour will be generated. With the start of the Carnalita project, Sergipe's industrial production is expected to increase by a third, thereby increasing tax collection. In addition, Sergipe is already a traditional fertilizer producer, through FAFEN-SE and Taquari-Vassouras; for this reason, it has the logistical structure required. The facility is close to highway BR-101 and to the Inácio Barbosa Maritime Terminal. There is guaranteed availability of natural gas in the region (Sergipe 2014). The project was sold, along with other assets, to Mosaic in 2018.

Doubts remain about the reassessment of the Carnalita Project by Mosaic Fertilizantes P\&K (In The Mine 2018). In the global context, the potash industry has recently shown overcapacity and depressed sales value. Still, potassium from Sergipe (carnallite) requires a technological route that increases the production cost when compared to potassium from sylvinite.

Another promising project involving the mining and processing of potash in Brazil is the Autazes Project. According to Potássio do Brasil (2015b), the ore will be extracted through mechanized underground mining. Installed processing will probably use the solution/crystallization process. A production capacity of 2.2 million tons of $\mathrm{KCl}$ per year is estimated, equivalent to 1.3 million tons of $\mathrm{K}_{2} \mathrm{O}$. As a by-product, 1.1 million tons of $\mathrm{NaCl}$ shall be produced. Initial CAPEX is estimated at US $\$ 1.8$ billion. In February 2015, the company announced plans to start operating the plant in 2019.

Data on potash reserves in Brazil come from different sources. It is estimated that Brazil has $\mathbf{3 1 0}$ million tons in recoverable sodium chloride deposits, with 24 million tons of $\mathrm{K}_{2} \mathrm{O}$ content (USGS 2019). Brazilian potash reserves (USGS 2020) are located in the states of Sergipe, Bahia, Amazonas and Pará. However, measured reserves are only found in Taquari-Vassouras (Sergipe), Santa Rosa de Lima (Sergipe), Fazendinha - Nova Olinda (Amazonas), Arari - Nova Olinda (Amazonas) and Autazes (Autazes).

The reserves in Taquari-Vassouras, in the state of Sergipe, were discovered in 1963 by Petrobras, while prospecting for oil in the region. They are composed of sylvite and carnallite. The project for the mine was implemented in 1979, and the operations started in 1985 by Petrobras Mineração S.A. It belonged to Petrobras until 1991, when it was acquired by Vale (Farias 2015).

Currently owned by Mosaic Fertilizantes P\&K, the TaquariVassouras industrial complex, in Rosário do Catete (SE), has a railway (9 km away from the complex) and a port (40 km away from the complex). The underground operation takes place over a space that comprises three municipalities: Rosário do Catete, Capela and Carmópolis. On December 31, 2018, recoverable reserves were estimated at 11.4 million tons, with $\mathrm{K}_{2} \mathrm{O}$ content of $23.55 \%$. Also, the reserves are expected to be depleted in 2023. The reserve still belongs to Petrobras, and Mosaic Fertilizantes P\&K paid around US\$5 million in 2008 (Mosaic 2019c).

The Carnalita Project was conceived by Vale and is now under the control of Mosaic Fertilizantes P\&K. According to DNPM (2015), Sergipe's total carnallite reserves (measured, indicated and inferred reserves) amount to 14.4 billion tons, with $10.40 \%$ of potassium chloride. IBRAM (2015) has published data compatible with such an order of magnitude: The measured reserves of potash (sylvinite and carnallite) amount to 9,446,315 tons (with 935,466 tons of $\mathrm{K}_{2} \mathrm{O}$ ) while the indicated potash reserves (sylvinite

and carnallite) amount to $3,592,920$ tons (with 308,138 tons of $\mathrm{K}_{2} \mathrm{O}$ ). However, the carnallite reserves, in the order of billions, were evaluated in the 1960s and, therefore, a reassessment should be made. Vale (Vale 2017), who prepared the project at the time, stated that the proven reserves are estimated at 247.1 million tons and that the probable reserves are estimated at 54.5 million tons (both with an estimated content of $12.2 \% \mathrm{KCl}$ ). Thus, the total reserves of the Carnalita Project amount to a total of 301.6 million tons of potassium chloride, which corresponds to 36.79 million tons of $\mathrm{KCl}$ or 23.25 million tons of $\mathrm{K}_{2} \mathrm{O}$. Such reserves would take more than 20 years to be exhausted.

In the North Region of the country, the most important potash reserves are those of Autazes and Nova Olinda. According to the company Brazil Potash (Potássio do Brasil 2015a), in a public hearing at the Brazilian Federal Senate, research around the deposit began in 2009, with 60 drill holes and more than 50,000 meters of drilling. The final report was presented to DNPM (currently, ANM) in 2014 and more than 100 million dollars were invested to carry out this research. The project, which involves investments in the order of magnitude of 2 billion dollars, aims to produce 8 million tons of ore per year, resulting in 2.16 million tons of $\mathrm{KCl}$ and 1.1 million tons of $\mathrm{NaCl}$ per year. Such annual production capacity is equivalent to 1.36 million tons of $\mathrm{K}_{2} \mathrm{O}$ In a presentation to investors (Potássio do Brasil 2015b), the company stated that the "Potassium Basin from Amazonas" is among the three most important in the world, compared to the basins in Saskatchewan (Canada) and Urals (Russia). Furthermore, it is assumed to have similar scale, geological characteristics and age to that of Saskatchewan.

These deposits are located in areas adjacent to Fazendinha and Arari, which are potash deposits discovered by Petrobras in the late 1970 s and estimated, at the time, to contain more than 1 billion tons of potassium mineral reserves. The most prominent discovery, the Autazes deposit (Table 3) has measured/ indicated reserves of 425 million tons (with $32.0 \% \mathrm{KCl}$, or 85.97 million tons of $\mathrm{K}_{2} \mathrm{O}$ ) and inferred reserves of 301 million tons (with $30.6 \% \mathrm{KCl}$, or 58.23 million tons of $\mathrm{K}_{2} \mathrm{O}$ ). These estimates were based on 39,540 meters of drilling ( 34 holes) and cutting points with $10 \% \mathrm{KCl}$ at 1 meter depth. The deposit is up to 4.0 meters thick, with average thickness of 2.3 meters, with depth ranging between 685 meters and 863 meters, smoothly extending towards the southeast. The estimates were made by the company Ercosplan (Ercosplan Ingenieurgesellschaft Geotechnik und Bergbau), which prepared the technical report NI-43101 (Potássio do Brasil 2015b).

Despite the favorable characteristics of the main raw material (that is, the mineral with considerable potassium contents), the fact that such deposits are in the Amazon region

TABLE 3. Potash reserves in Autazes (Potássio do Brasil 2015b).

\begin{tabular}{l|c|c|c|c}
\hline $\begin{array}{l}\text { Autazes } \\
\text { Deposit }\end{array}$ & Total (MT) & \% de $\mathbf{K C l}$ & $\mathbf{K C l}(\mathbf{M T})$ & $\mathbf{K}_{\mathbf{2}} \mathbf{O}(\mathbf{M T})$ \\
\hline $\begin{array}{l}\text { Measured } \\
\text { Reserves }\end{array}$ & 127.9 & 32.5 & 41.6 & 26.3 \\
\hline $\begin{array}{l}\text { Indicated } \\
\text { Reserves }\end{array}$ & 297.5 & 31.8 & 94.6 & 59.8 \\
\hline $\begin{array}{l}\text { Measured+ } \\
\text { Indicated } \\
\text { Reserves }\end{array}$ & 425.4 & 32 & 136.2 & 86.1 \\
\hline $\begin{array}{l}\text { Inferred } \\
\text { Reserves }\end{array}$ & 300.6 & 30.6 & 92.0 & 58.1 \\
\hline
\end{tabular}


is an unfavorable factor. Owing to impasses with the local indigenous community, the Federal Public Ministry issued a recommendation arguing that the Environmental Protection Agency of Amazonas (IPAAM) should cancel the previously issued license and that Potássio do Brasil should suspend research activities in the region until consultations had been performed, as provided for by law (MPF 2019).

In February 2018, Brazil Potash highlighted, once again, the importance of access to raw materials as decisive factor for the project to be successful: The reserves (proven and probable) are capable of maintaining a production of 2.4 million tons of $\mathrm{KCl}$ (a value equivalent to 1.52 million tons of $\mathrm{K}_{2} \mathrm{O}$ ) for a period of 34 years, using only $10 \%$ of the area required for mineral activities (Potássio do Brasil 2018).

According to Golder Associates (2015), water availability is not a problem in the project's region: "The high flow rates of the water courses crossing it ensure the possibility of capturing these surface waters without causing any conflict in the use of water resources". The water to be used in the project would be collected from the Madeirinha River. Electricity is widespread in the region, especially in urban centers. Along the banks of the various rivers, the energy of the local population is supplied by generators.

Of recognized importance a few decades ago, the deposits discovered by Petrobras in the Nova Olinda (AM) region were discovered in 1955 . The rock salt layers in the region are associated with the sequence of Upper Paleozoic evaporites. After that year, new reserves were discovered in the Tapajós, Nhamundá-Trombetas and Nova Olinda-Maués regions. The Nova Olinda deposit is formed by evaporite chemical sediments located in the upper Carboniferous part of the Amazon Basin. In this region, there are horizons of rock salt, potassium salts, gypsum, anhydrite and limestone (Lapido-Loureiro et al. 2008). Official reserves (measured) in Nova Olinda (deposit in Fazendinha and deposit in Arari) are estimated at a total 493 million tons, equivalent to 99.09 million tons of $\mathrm{K}_{2} \mathrm{O}$ (DNPM 2015). There is a great dela of news but little certainty about the exploration of such deposits in Nova Olinda. In the year 2006 (Nakamura 2006), Petrobras has shown an interest in selling its mineral rights concerning the exploration of potash in Amazonas. Inherited from Petromisa in 1991 (a state-owned mining company that was dissolved under former Brazilian President Fernando Collor's government), such mining rights were going be offered in a single installment; at the time, companies such as Bunge, Votorantim and Vale were interested in acquiring these assets. In the year 2008 (Agência Estado 2009), there were negotiations with the company Falcon Metais to sell a mine in Fazendinha; however this transaction was not concluded. In the same year, the DNPM granted Falcon Metais three exploration permits in the Madeira River region (which were transferred, a posteriori, to the company Brazil Potash). Recently, Petrobras (through its annual reports, financial reports and/or sustainability reports) has not made any public statements about such potash resources (Petrobras 2020).

\subsubsection{World (Canada)}

Canada, the world's largest producer and exporter of potash, has large companies that carry out potash mining and processing activities: Mosaic Company, Nutrien, K+S, among others. Mosaic, previously discussed, operates three mining complexes in Canada: Colonsay (shaft mining), Belle Plaine (solution mining) and Esterhazy (shaft mining). All of them are located in the Saskatchewan Province, and they have been carrying out projects for expansion (brownfield projects, that is, expansion of existing ventures) of production capacity in recent years (Figure 9).

The Esterhazy complex (Mosaic Company) has a

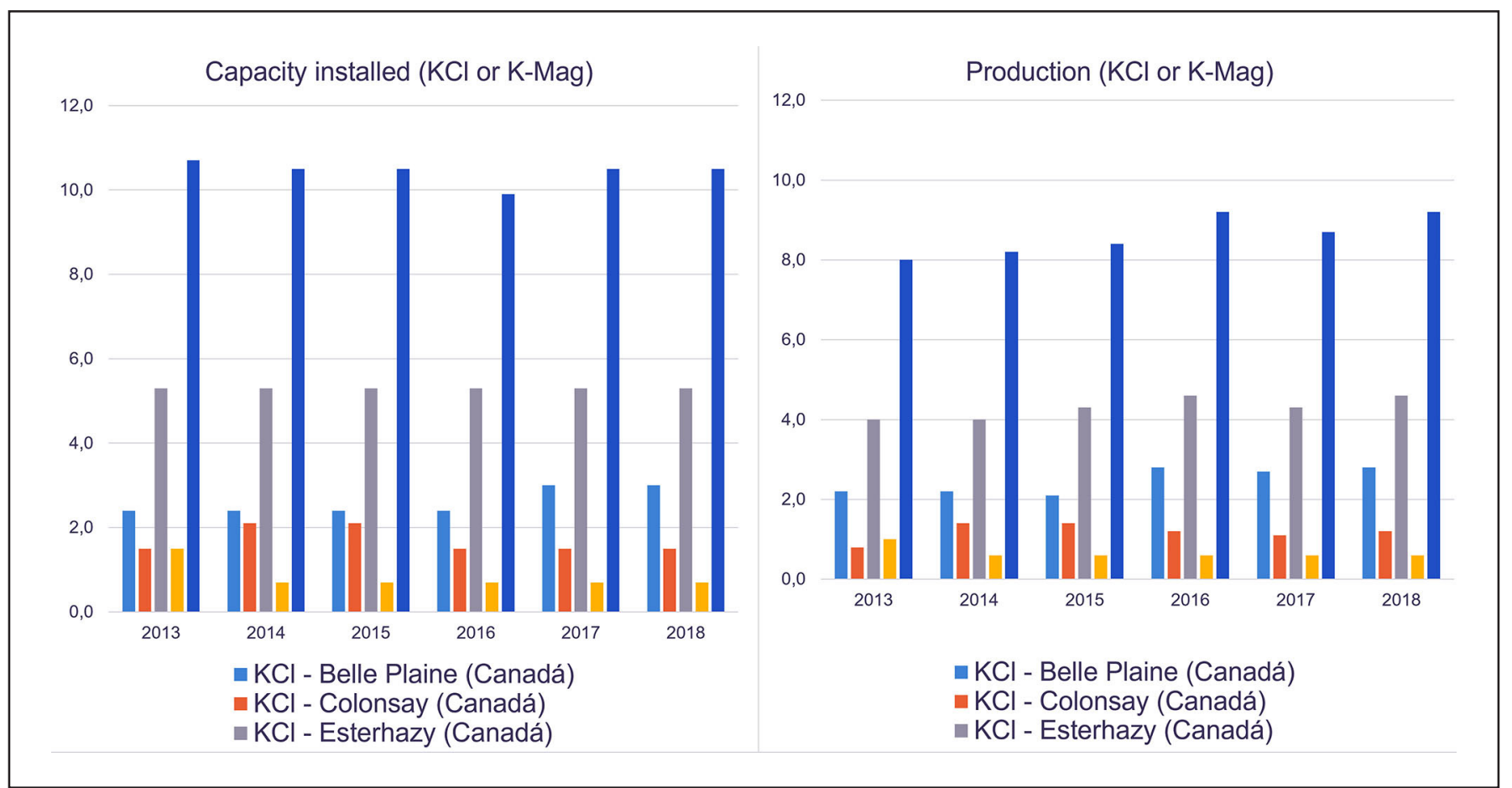

FIGURE 9. Mosaic's installed and production capacity from 2013 to 2018 (Mosaic 2014, 2019c). 
production capacity of 5.3 million tons of potassium chloride per year (finished product). In 2018, to produce 4.6 million tons of potassium chloride, 13.9 million tons of ore were extracted (with an average $\mathrm{K}_{2} \mathrm{O}$ content of $23.7 \%$ ). The mine's reserves are estimated at 879 million recoverable tons, with an average $\mathrm{K}_{2} \mathrm{O}$ content of $24.7 \%$ (Mosaic 2019c).

In 2008, Mosaic announced an expansion program for potash production to increase total production capacity by 3 million tons per year. Project K3 foresees an additional mine (compared to the two preexisting mines, Esterhazy K1 and Esterhazy K2), with the addition of a production capacity of 900,000 tons per year between 2017 and 2018 (Mosaic 2014). There are plans for investment of 1.7 billion dollars in the project (Giles, 2015). According to the company (Mosaic 2015), a total amount of 1.5 billion is to be invested in the period between 2014 and 2024. Transportation infrastructure needs to be developed to enable the processing of the mineral in the preexisting structure (in Esterhazy K1 and Esterhazy K2). Furthermore, such an increase in production capacity would create operational flexibility capable of mitigating risks concerning brine inflow, a recurring problem in Esterhazy.

The Belle Plaine complex (Mosaic Company) has a production capacity of 3.0 million tons of potassium chloride per year (finished product). In 2018, to produce 2.8 million tons of potassium chloride, 10.6 million tons of ore were extracted (with an average $\mathrm{K}_{2} \mathrm{O}$ content of $18.0 \%$ ). The mine's reserves are estimated at 819 million recoverable tons, with an average $\mathrm{K}_{2} \mathrm{O}$ content of $18 \%$. In the years 2018 and 2017, production capacity in Belle Plaine was 600,000 tons higher than in 2016 (Mosaic 2019c).

Mosaic planned to expand its potash production in Belle Plaine by 2.8 million tons, with a total investment of 2.3 billion dollars. The project would include increasing the processing capacity of the potash refinery, as well as new facilities and utilities. Driven by the growing demand at the time for potassium fertilizers, the project would provide the existing facility with an installed capacity of up to 5.3 million tons in 2020 (Canadá 2009a). However, expansion projects in Belle Plaine were postponed indefinitely in 2013 (Argus 2013). The increase in production capacity to 600,000 tons between 2016 and 2017 corresponds to stage one of this project, which was not postponed. The amount invested exclusively in this project was not informed (Mosaic 2018).

The Colonsay complex (Mosaic Company) has an annual production capacity of 1.5 million tons of potassium chloride per year (finished product). In 2018, to produce 1.2 million tons of potassium chloride, 3.4 million tons of ore were extracted (with an average $\mathrm{K}_{2} \mathrm{O}$ content of $26.8 \%$ ). The mine's reserves are estimated at 295 million recoverable tons, with an average $\mathrm{K}_{2} \mathrm{O}$ content of $26.3 \%$. Inaugurated in 1969 , the production capacity of the mine has been recently expanded, in a process that was completed in 2014. In 2014, Mosaic claimed to have expanded the mine's annual production capacity by 600,000 tons, reaching a total value of 2.1 million tons per year. However, in July 2016, Mosaic (Mosaic 2017) opted to reduce part of the mine's productive capacity in Colonsay - owing to low price conditions in the potash market - and supply such market in order to reduce its inventory. This mine had a higher operating cost than the others.

Nutrien is a company arising from the merger of Agrium and PotashCorp in 2017 and has a production capacity of 20.6 million tons of potassium chloride (Table 4). In 2018, it produced 12.84 million tons of potassium chloride, with all production located in Saskatchewan Province - Canada (Nutrien 2019b). Of the potassium chloride production assets belonging to Nutrien, Vanscoy Potash comes from Agrium, and the others come from PotashCorp (Agrium 2018; PotashCorp 2018).

The installed capacity of the Rocanville Potash unit $(6.5$ million tons per year) is the result of a project that has virtually doubled its capacity. With an investment of 3 billion dollars, a new mill, a new deposit for 500,000 tons, and a new transport system for the ore were built. Still, the shaft that was used for services was converted into a production shaft (Lazenby 2017).

Currently with an operating capacity of 2.8 million tons per year, the Allan Potash unit underwent an expansion process that increased its annual production capacity by about one million tons. The planned investment was 550 million dollars in 2011(Mining 2011).

The Vanscoy Potash unit, which previously belonged to Agrium, went through an expansion process (completed in 2015) that increased its installed capacity by 1 million tons per year (Agrium 2016). According to The Canadian Press (2014), the company's executives estimated the project at 2.3 billion dollars at the end of 2014, an amount $53 \%$ higher than estimated at the beginning of the project.

In 2009, a project to expand production capacity at the Cory Potash unit was started, increasing production capacity from 2 million tons per year to three million tons. This project included expansion of the flotation and compaction unit, improvements to allow for additional lifting/mining/storage capacity, a new water reservoir and a new brine disposal system (Canadá 2009b). Canadian Mining (2009) announced that the planned investments were 220 million dollars.

The company $\mathrm{K}+\mathrm{S}$ Potash Canada, part of the $\mathrm{K}+\mathrm{S}$ group (a German company that has been mining and processing potash and salt since the 19th century), has recently opened

TABLE 4. Nutrien's production and production capacity in MT (Nutrien 2019b).

\begin{tabular}{|c|c|c|c|c|c|}
\hline Unit & $\begin{array}{c}\text { " Nominal } \\
\text { Capacity } \\
\text { (MT)" }\end{array}$ & $\begin{array}{c}\text { "Operational } \\
\text { Capacity } \\
2019 \\
\text { (MT)" }\end{array}$ & $\begin{array}{c}\text { "Operational } \\
\text { Capacity } \\
2018 \\
\text { (MT)" }\end{array}$ & $\begin{array}{c}\text { "Production } \\
2018 \\
\text { (MT)" }\end{array}$ & $\begin{array}{l}\text { Production } \\
2017 \\
\text { (MT)" }\end{array}$ \\
\hline Rocanville & 6.5 & 5.4 & 5.2 & 5.22 & 4.86 \\
\hline Allan & 4.0 & 2.8 & 2.6 & 2.41 & 1.83 \\
\hline Vanscoy & 3.0 & 2.2 & 2.7 & 2.24 & 2.42 \\
\hline Lanigan & 3.8 & 2.1 & 2 & 1.96 & 1.82 \\
\hline Cory & 3.0 & 1.0 & 0.8 & 0.81 & 0.99 \\
\hline Patience lake & 0.3 & 0.3 & 0.3 & 0.2 & 0.3 \\
\hline Total & 20.6 & 13.8 & 13.6 & 12.8 & 12.2 \\
\hline
\end{tabular}


the Bethune mine (in Saskatchewan, Canada). In 2018, 1.4 million tons were produced at this unit $(K+S$ 2019). Opened in May 2017, the mine uses solution mining technology, has reserves of 214 million tons of potassic rocks, and 885 million tons of resources. Announced in 2010, the greenfield project in Saskatchewan was expected to receive investments in the order of 4 billion dollars (K+S 2020) and expects to reach potash production capacity of 2.86 million tons per year in the long term. (K+S 2018).

Canada is the 'epicenter' of world potash production. Most of the country's potash mines are located in the province of Saskatchewan. With exploration potential known since 1946 (after prospecting for oil and natural gas in the region), it has deposits in the order of five billion mineable tons. Potassium salts probably formed as a secondary precipitate just below the surface and were modified to different degrees by the passage of fluids in the deposition environment. The continuous deposition cycle was possible owing to the combination of nearby sources of salts and strong winds. (Warren 2006). Currently, most potash produced in Saskatchewan is in the hands of two companies: Mosaic Company and Nutrien.

Mosaic's potash mines have a considerable number of recoverable reserves: Belle Plaine has 819 million tons (18.0 $\%$ of $\left.\mathrm{K}_{2} \mathrm{O}\right)$, Colonsay has 295 million tons $\left(26.3 \%\right.$ of $\left.\mathrm{K}_{2} \mathrm{O}\right)$ and Esterhazy has 879 million tons $\left(24.7 \%\right.$ of $\left.\mathrm{K}_{2} \mathrm{O}\right)$. Also, in terms of existing mineralization that extends beyond the areas of these mines (within an additional 16-mile radius), Mosaic claims that there are potentially recoverable deposits: Belle Plaine, with 2.363 billion tons; Colonsay, with 441 million tons; and Esterhazy, with 674 million tons. In this case, $\mathrm{K}_{2} \mathrm{O}$ contents have not been disclosed. Furthermore, Mosaic believes that the available amount of these reserves is sufficient to maintain production (considering the current level) for more than a century (Mosaic 2019c).

The Belle Plaine unit, which is the world's largest mine exploited by the solution mining method, needs large amounts of natural gas to produce steam and dry the product. At the company's other units, natural gas input is used to heat the air inside the mines and to dry the products (Mosaic 2019a). The Belle Plaine unit alone consumed $78 \%$ of the natural gas acquired by Mosaic (when considering only the Potassium business segment) in 2018 (17 million mmBtu). In 2018, the average price paid by the company was US $\$ 3.16 / \mathrm{mmBtu}$ (Mosaic 2019c).

Mosaic (Mosaic 2019b) has informed that, in 2018, it used $4.52 \mathrm{~m}^{3}$ of water to produce 1 ton of fertilizer, considering all business segments. The total volume of consumption was $403,010,000 \mathrm{~m}^{3}, 283,603,000$ of which $(70.4 \%)$ came from surface water, $45,264,000 \mathrm{~m}^{3}(11.2 \%)$ from reconditioned water, $1,296,000 \mathrm{~m}^{3}(0.4 \%)$ from the municipal supply system and $72,847,000$ (18.1\%) from groundwater. However, Mosaic has not disclosed, in its annual reports (annual report, 10-k report or sustainability report), the amount of water consumed exclusively by the Potassium business segment.

In 2018, Mosaic consumed 119.34 million gigajoules, (considering all its business units); $61.07 \%$ of this amount came from reused steam (mostly used in the phosphate segment, originating in excess steam during production of sulfuric acid), $24.47 \%$ from natural gas, $5.69 \%$ from cogeneration of electricity and $8.77 \%$ from petroleum products. Such consumption is reported by the company as "total direct energy consumption by source". Of this total amount (119.34 million gigajoules), only
$16 \%$ is consumed by the potash business segment. Mosaic has stressed the importance of the cost of these inputs for the company's results, and highlighted the role of natural gas prices for the potash segment (Mosaic 2019c).

According to MDS (2020), Nutrien has reserves (proved and probable) in: Rocanville, with 543 million tons $(23.4 \%$ of $\left.\mathrm{K}_{2} \mathrm{O}\right)$; Allan, with 349 million tons $\left(25.9 \%\right.$ of $\mathrm{K}_{2} \mathrm{O}$, particularly in the year 2018); Vanscoy, with 232.1 million tons (approximately $25 \%$ of $\mathrm{K}_{2} \mathrm{O}$ ); Lanigan, with 540 million tons ( $\%$ of $\mathrm{K}_{2} \mathrm{O}$ not disclosed); Cory, with 248 million tons (22.5\% of $\left.\mathrm{K}_{2} \mathrm{O}\right)$; and Patience Lake (reserves not disclosed; $\mathrm{K}_{2} \mathrm{O}$ content not disclosed). Based on data disclosed by the company, shaft mining is carried out in all these six mines (Nutrien 2019b).

In 2018, Nutrien produced 12.84 million tons of potassium chloride, 6.37 million tons of ammonia and 1.85 million tons of phosphates (in terms of $\mathrm{P}_{2} \mathrm{O}_{5}$ content). To do so, the company had to explore 39.6 million tons of potassium ore, acquire 146 billion cubic feet of natural gas (or 4.13 billion $\mathrm{m}^{3}$ ), explore 5.9 million phosphate rocks, use 289,500 terajoules of energy, use 208 million $\mathrm{m}^{3}$ of water. In its sustainability report, Nutrien does not disclose such amounts of inputs consumed separately by business segment (Nutrien 2019c).

All the water used in the production of potassium comes from local underground reservoirs close to the mines. These reservoirs offer a sustainable supply of water, as needed for milling operations. In Allan, water is provided by a local reservoir called the Bradwell Reservoir, operated by the SaskWater company. Lanigan also uses water from this reservoir, as well as water from the Hatfield Valley aquifer. In Cory, the water in use comes from the South Saskatchewan River along a 10-kilometer line. In Rocanvile, water is collected from two aquifers (Welby Plains Surficial Aquifer and Welby Plains Middle Aquifer). In Vanscoy, water comes from the South Saskatchewan River (Nutrien 2019b).

The energy used by Nutrien $(289,500$ terajoules in 2018 ) comes from natural gas $(54.1 \%)$, fossil fuels $(39.0 \%)$, purchased electricity (15.3\%), and imported steam (1.5\%). For all its products, the company uses 12.04 gigajoules of energy per ton of product. Thus, little can be concluded regarding the use of energy and water for the production of potash fertilizers by the Nutrien company (Nutrien 2019c). As reported by Mosaic, Nutrien's financial results are also heavily affected by natural gas prices. Nutrien purchased, on average, natural gas at a price of $\$ 2.83$ per mmBtu in 2018 . Nutrien recently entered into a long-term contract aimed at acquiring natural gas in Trinidad and Tobago. However, such supply is likely to supply US operations, which do not include potash production (Nutrien 2019a).

\subsubsection{World (Russia)}

Russia, which produced 7.5 million tons of potash fertilizers in 2018 (in terms of $\mathrm{K}_{2} \mathrm{O}$ content), concentrates its potash production in the Uralkali company. With 5 mines (Solikamsk-I, Solikamsk-II, Solikamsk-III, Berezniki-II and Berezniki-IV), 6 processing units (Solikamsk-I, Solikamsk-II, SolikamskIII, Berezniki-II, Berezniki-III and Berezniki-IV), 3 licenses to explore new blocks (Romanovski Block, Ust-Yayvinsky Block and Izversky Block), a license to conduct geological studies and a carnallite processing plant (Solikamsk-I), the company produced 11.5 million tons of potassium chloride in the year 2018 (which corresponds to about 6.7 million tons of $\mathrm{K}_{2} \mathrm{O}$ ) and 
12.7 million tons of potassium chloride in the year 2018 (which corresponds to about 7.3 million tons of $\mathrm{K}_{2} \mathrm{O}$ ). These quantities correspond to the total potash production in Russia. Uralkali reports that it is currently allocating its resources for the expansion of potash production in Solikamsk-II (construction of a new mine), Solikamsk-III (expansion of production capacity), Solikamsk-I (expansion of production capacity of carnallite), development of the Ust-Yayvinsky Block (Uralkali 2019).

Started in 2011(Uralkali 2011), the mine construction project in Ust-Yayvinsky foresees an investment of 1.9 billion dollars and an annual production capacity of 2.5 million tons of potash (Vorotnikov 2015).

The project for the construction of a new mine in Solikamsk-II (which also includes the construction of a transport system that takes ore from the new mine to the existing potash processing facilities) foresees an increase in production capacity to 2.2 tons of million tons potassium chloride per year, thus requiring an investment of 723 million dollars (Uralkali 2016). Importantly, in November 2014, the existing mine at Solikamsk-2 collapsed (owing to a high level of brine inflow), which resulted in a huge crater (Globo 2014). The production of Uralkali (Uralkali 2017) was decreased as a consequence (12.1 million tons of potassium chloride in 2014, 11.4 million in 2015 and 10.8 million in 2016).

The project for expansion of Solikamsk-3 foresees an increase of 0.6 million tons of potassium chloride per year, with an estimated investment of 135 million dollars (Vorotnikov 2015) The initial project, which foresaw an expansion of 2 million tons per year and an investment of 1 billion dollars, was postponed in 2013 owing to the market situation for potassium fertilizers (Nickel 2013).

Russia produced 7.5 million tons of potassium chloride in 2018 and has the largest reserve of this mineral: $2,000,000$ tons of recoverable potassium chloride, both in terms of $\mathrm{K}_{2} \mathrm{O}$ content) (USGS 2019). Potash production in Russia, exclusive by the Uralkali company, is concentrated in the Perm Region (about $1500 \mathrm{~km}$ east of the Russian capital, Moscow), with 5 mines (Solikamsk-I, Solikamsk-II, Solikamsk-III, Berezniki-II and Berezniki-IV), 6 processing units (Solikamsk-I, SolikamskII, Solikamsk-III, Berezniki-II, Berezniki-III and Berezniki-IV), 3 licenses for exploration of new blocks (Romanovski Block, Ust-Yayvinsky Block and Polovodovski Block), a license to conduct geological studies and a carnallite processing plant (Solikamsk-I). All of them are located in the Upper Kama (or Verkhnekamskoye) deposit, which is the second largest deposit in the world. The reserves (most indicated measures) under the company's mining rights amount to a total of 7 billion tons of ore, with an average $\mathrm{K}_{2} \mathrm{O}$ content of $18.9 \%$ (Uralkali 2019).

in 2018 (Uralkali 2019), 11.1 million tons of potash sold were sold at an average of $\$ 212.00$ per ton, generating a net income of $\$ 2.281$ billion. Such revenue also includes services such as freight, wagon leasing, etc. Costs to achieve results this year (total of 702.9 million dollars) include the cost of depreciation (25.1\%), cost of labor $(23.9 \%)$, material inputs (16, $4 \%)$, fuels $(14.5 \%)$, maintenance $(9.2 \%)$ and amortization of mining licenses (7.7\%). The COGS indicator (Cash Cost of Goods Sold), which disregards amortization and depreciation costs, shows that the company spent US $\$ 42.50$ to produce a ton of product in 2018.

Gazprom is an important Russian company, operating in more than 20 countries and present in the market of more than 130 countries. In 2018, Gazprom produced 498.7 billion cubic meters of natural gas, or around $75 \%$ of Russia's natural gas production. For the domestic market, Gazprom claims to have sold it (taxes not included) at prices of RUB $3815 / \mathrm{Mm}^{3}$ (in 2016), RUB $3808 / \mathrm{Mm}^{3}$ (in 2017) and RUB $3981 / \mathrm{Mm}^{3}$, in 2018 (Gazprom 2018). Converted, these data are equivalent to values between US\$ 2 / mmBtu and US\$ 3 / mmBtu for the domestic market - taxes not included.

\subsubsection{World (Belarus)}

In Belarus, which produced 7.1 million tons of potassium fertilizers in 2018 (in terms of $\mathrm{K}_{2} \mathrm{O}$ content), the Belaruskali company was accountable for most potash production. Belaruskali's assets includes 6 mines (operative), authorization to explore 4 additional mines, 4 processing plants, mixing and formulation units, and distribution and sales structure. It also produces potassium hydroxide, sodium hypochlorite, and hydrochloric acid (Argus 2019). The company produced 12 million tons of $\mathrm{KCl}$ in 2018 (equivalent to 6.96 million tons of $\mathrm{K}_{2} \mathrm{O}$, a value compatible with the total national production of Belarus) (Woodroof, 2019).

According to Belarus (2014), Belaruskali started, in 2014, the construction of the Petrikov Project, which comprises a mine and a potassium chloride processing unit with initial capacity of at least 1.5 million tons per year (which can be expanded to 3 million tons per year). The Petrikov deposit has reserves of up to 2.2 billion tons of potassium ore (expectation), which would ensure 90 years of production autonomy. On September 7, 2018, the first ore extraction took place in Petrikov (Belta, 2019). As reported by Micetimes (2019), the project is expected to be completed in December 2019 and will reach full capacity (3 million tons per year) in 2021. Belaruskali's president stated that an investment of 1 billion dollars is required to create an installed capacity of 1 million tons (Loiko, 2019). This way, the order of magnitude of the Petrikov Project can be inferred: around 3 billion dollars.

Belaruskali does not directly market its products: the company BPC (Belarusian Potash Company) was established in 2013 with the aim of structuring Belaruskali's potassium export and marketing operations, supplying the worldwide demand for this nutrient and maintaining market stability for this product (Argus 2019).

In the year 2018, Belarus produced 7.1 million tons of potassium chloride (in terms of $\mathrm{K}_{2} \mathrm{O}$ content). Furthermore, the country has the world's third largest reserve of potassium chloride: 750 million recoverable tons (USGS 2019).

The structure of the production of potassium chloride in Belarus focuses on the assets of the Belaruskali company: 6 operating mines, authorization to explore 4 additional mines, 4 processing plants, nutrient formulation/distribution facilities and potassium hydroxide production assets (which add value to the production chain). On its website, the company does not disclose reports (annual, financial, sustainability or others). Such lack of information hinders the collection of information about access to raw materials in Belarus. The company's website shows the fact that it is a JSC (Joint Stock Company), that is, the company belongs to investors who own shares, but there is no information about its relationship with such investors. It is predominantly state-owned company (Reuters, 2020).

The main potash deposits in Belarus are found in the Pripyat Basin (Cocker et al., 2017). Exploration started in 1963 at the Starobin-I mine. It is currently one of the main 
producing countries of this commodity, and the Pripyat Basin is consolidated as the world's third largest reserve (behind Saskatchewan, Canada, and Upper Kama, Russia). Total reserves are estimated at 7.3 billion ore, which means 1.3 billion tons of $\mathrm{K}_{2} \mathrm{O}$. Most of these reserves are located in the regions close to the Starobin and Petrikov mines.

The deposits at Berezovsky (active mine) have 240 million tons to be extracted (data from $2012, \mathrm{~K}_{2} \mathrm{O}$ content not disclosed) (USGS, 2020). The deposits in Krasnoslobodsky (active mine) have 345 million tons, with $14.9 \%$ of $\mathrm{K}_{2} \mathrm{O}$ (data from 2006). Darasinsky's reserves were not disclosed, and the mine was planned to open in 2020. Starobin I, II and III (Production Unit 1,2 and 3 ) have reserves of $4,420 / 7,200 / 3,370$ million tons, with $670 / 1,130 / 800$ million tons of $\mathrm{K}_{2} \mathrm{O}$, respectively. However, such data on Starobin date back to the 1980s. Petrikov, where Belaruskali is setting up its new mining unit, has 1.989 billion tons to be mined, with 415 million tons of $\mathrm{K}_{2} \mathrm{O}$ (data from 2011).

According to BP (2019), the country consumed 19.3 billion cubic meters of natural gas in 2018. In the same year, it was reported that the country purchased 19.0 billion cubic meters from Russia. As published by the Russian News Agency (2018), the price of Russian natural gas paid by Belarus was $\$ 129$ per $1,000 \mathrm{~m}^{3}$ in the year 2018 (converted, such amount is approximately US\$3.65/ mmBtu). This estimated value reflects the price paid by the country to import natural gas; consequently, prices will be higher for end consumers. For comparison purposes, resuming data from BP (2019), such price charged by Gazprom (Russian gas company) and paid by Belarus is lower than the indexes "Average German Import Price" (US\$ 6.62 / mmBtu in 2018), "Heren NBP Index" (US\$ $8.06 / \mathrm{mmBtu}$ in 2018) and "Netherlands TTF" (US\$7.90 / $\mathrm{mmBtu}$ in 2018). However, it is higher than the one charged by the Henry Hub (US\$3.13/mmBtu in 2018) and AlbertaCanada (US\$1.12 / mmBtu) indices.

\subsection{Level of technology mastery}

The potash fertilizer industry has reported greater challenges and difficulties in the stage of potassic rock mining, and this is the aspect that will be addressed. Mosaic (Mosaic 2019c) reported recurring risks posed by brine inflow in its mines using the traditional mining process in Saskatchewan (especially the Esterhazy mine). The Brazilian TaquariVassouras mine (Baltar et al. 2001) faced risks of flooding because there are several subterranean rivers in that mining region. Furthermore, it poses challenges to the geotechnical stability of the mine, as a result of the presence of a highly hygroscopic mineral (tachyhydrite). In Russia (Globo 2014; Uralkali 2017), a mine belonging to the Solikamsk-II complex collapsed, creating a huge crater in the region. This event interrupted the operations and has deeply impacted the potash sector.

In Brazil, the production of potassium chloride (in TaquariVassouras) was started in 1986 by the company Petromisa. Petromisa was originally founded, back in 1978, with the purpose of exploring potassium in Sergipe (which had been discovered in 1963). At the time, poor assessments of the complexity of the works and the cost of the project delayed the start of operations in Sergipe for several years (CPDOC 2020). The construction of the mine in Taquari-Vassouras has unique exploration difficulties: the presence of explosive gases in the mine (nearby oil fields), location at great depth
(450 meters) and likelihood of flooding by aquifer formations. Furthermore, tachydrite can be found in the vicinity (just below the mineral layer); it is highly hygroscopic and has low mechanical resistance, which makes geomechanical exploration more difficult to perform. The deposit is located in the Ibura member of the Muribeca formation. The formation of this deposit is attributed to a series of evaporites linked to the event of separation from the Afro-Brazilian continent, during the Early Cretaceous. There has been mineralization of halite, sylvinite and leached carnallite and tachydrite. Mining is underground and uses the method of chambers and pillars. The mineral is mined, and is then sent to a crushing plant, as well as concentration, drying and compaction units. The flotation method is used (Baltar et al. 2001).

There was a clear need to import technology to build the mine (Brasil, 1983). Two years later, Petromisa's president at the time explained the origin of the imported technology used by the company: France (Brasil 1985). In the same year of 1985, France mined 12.2 million tons of potassic rock, which were processed and corresponded to 1.75 million marketable tons of $\mathrm{K}_{2} \mathrm{O}$ (Craynon 1985). Potassium deposits in the Alsace Region (border region between Germany and France) have been exploited on an industrial scale since 1858 (Rice and Davis 1927). During the 20th century, the French state-owned company Mines de Potasse d'Alsace (or MDPA) and the French privately-owned company Kali Sainte-Thérèse (KST) were accountable for phosphate exploration in the country. (Craynon 1985). MDPA provided Petromisa with technological expertise for the construction of Taquari-Vassouras (Martino, 1981).

Also, in the state of Sergipe, the most recent project (Projeto Carnalita) did not come off the ground. The use of this mining technology (solution mining) would have been unprecedented in the country. However, in 2008, Vale started a pilot mine with an estimated duration of 2 years. Two studies were started in 2004, and two wells were drilled in 2006 in the municipality of Maruim (Ambietec 2009). The company Vale itself developed the main technology for carnallite mining (Exame, 2011). Furthermore, the development of such technology was also going to be used in the international projects Rio Colorado, Neuquén and Kronau.

In the Autazes Project, mining will be underground and the extraction of ores will take place through two wells with elevators (shafts), one intended for the body of work and one for production and equipment. The difference is that sodium chloride tailings will be returned to the cellars (backfill), while in Taquari-Vassouras, such tailings are sent to the sea through brine pipelines. According to Golder-Associates (2015), during the first years of operation, it would not be possible to return the tailings to the underground mine, so they must be piled and stored. This pile of tailings, in turn, must prevent the rainwater that falls on it from flowing into rivers and streams in the region.

\section{Conclusions}

The analysis of the Strategic Diagnosis of the Potash Fertilizer Industry, showed the fragility of Brazilian production in comparison to the demand created by national agriculture. With only one productive unit in operation located in the Northeast Region, Brazil imports more than $96 \%$ of the consumed potassium inputs. The only active company in the national $\mathrm{KCl}$ exploration market is an important player in the global market; in recent years, it has showed its intention to increase 
its market share in the Brazilian fertilizer market. The company has idle installed capacity (potassium chloride) in Canada. Potássio do Brasil aims to start potash production in Brazil, and the company claims that its possible venture in Autazes has competitive advantages in terms of mineral reserves, proximity to the consumer market in MATOPIBA, lower transportation costs when compared to the main suppliers of $\mathrm{KCl}$ to Brazil and the availability of waterways. Brazil has disadvantages in terms of expanding access to the raw material of $\mathrm{KCl}$ : deposits in the Amazon are located in sensitive areas and deposits related to the carnallite project are apparently not as competitive (in terms of CAPEX) when compared to projects in Canada, Russia and Belarus. New projects in Brazil require larger investments in infrastructure than the ones in Canada, Russia and Belarus (because in these countries, most of the new projects are located in areas with ongoing mineral activity). Access to mining and processing technology does not indicate that it is, by itself, a relevant threat when economic, social and environmental aspects are disregarded. The proximity to the consumer market is an aspect to be explored: Brazil is one of the largest potash consumers in the world and this seems to be a consolidated growing trend. Once the fragility of this sector has been detected, prospective scenarios for this industry should be developed. As an instrument, it can support the formulation of public policies for this sector, which is essential to the agribusiness chain.

\section{Acknowledgements}

The authors thank the JGSB reviewers.

\section{Conflicts of Interest}

This research received no external funding. The authors declare no conflict of interest

\section{References}

Agência Estado. 2009. Eldorado do potássio atrai Petrobrás à Amazônia. Available online at: https://economia.estadao.com.br/noticias/ geral,eldorado-do-potassio-atrai-petrobras-a-amazonia,463044 (accessed on 15 July 2020)

Agrium. 2016. Annual report 2015. Unpublished report. Available online at: https://www.nutrien.com/sites/default/files/uploads/2017-08/2015 agrium annual report_0.pdf / (accessed on 23 July 2021).

Agrium. 2018. Annual report 2017. Unpublished report. Available online at: https://www.nutrien.com/sites/default/files/uploads/2018-02/2017\%20 AGRIUM\%20Annual\%20Report\%20FINAL.pdf / (accessed on 17 September 2020).

Ambietec. 2009. EIA-Rima projeto Carnalita de Sergipe. Unpublished report. Available online at: https://www.adema.se.gov.br/wp-content/ uploads/2017/03 / (accessed on 20 September 2020).

ANDA. 2013. Setor de fertilizantes - anuário estatístico de 2018. São Paulo, Associação Nacional para Difusão de Adubos (ANDA). Available online at: https://www.anda.org.br / (accessed on 30 September 2020)

ANDA. 2014. Setor de fertilizantes - anuário estatístico de 2018. São Paulo, Associação Nacional para Difusão de Adubos (ANDA). Available online at: https://www.anda.org.br / (accessed on 30 September 2020)

ANDA. 2015. Setor de fertilizantes - anuário estatístico de 2018. São Paulo, Associação Nacional para Difusão de Adubos (ANDA). Available online at: https://www.anda.org.br / (accessed on 30 September 2020).

ANDA. 2016. Setor de fertilizantes - anuário estatístico de 2018. São Paulo, Associação Nacional para Difusão de Adubos (ANDA). Available at: https://www.anda.org.br / (accessed on 30 September 2020).
ANDA. 2017. Setor de fertilizantes - anuário estatístico de 2018. São Paulo, Associação Nacional para Difusão de Adubos (ANDA). Available online at: https://www.anda.org.br / (accessed on 30 September 2020)

ANDA. 2018. Setor de fertilizantes - anuário estatístico de 2018. São Paulo, Associação Nacional para Difusão de Adubos (ANDA). Available online at: https://www.anda.org.br / (accessed on 30 September 2020)

ANDA.2019. Setor de fertilizantes - anuário estatístico de 2018. São Paulo, Associação Nacional para Difusão de Adubos (ANDA). Available online at: https://www.anda.org.br / (accessed on 30 September 2020).

Argus. 2013. Mosaic delays Saskatchewan potash expansion. Available online at: https://www.argusmedia.com/pt/news/846850-mosaicdelays-2mn-t-saskatchewan-potash-expansion / (accessed on 17 January 2020).

Argus. 2019. Argus FSU fertilizer 2019. Available online at: https://www. argusmedia.com/pt/conferences-events-listing/fsu-fertilizer/partners / (accessed on 22 January 2020).

Bain \& Company, Gas Energy. 2015. Study of the potential for diversification of the Brazilian chemical industry. 1st ed. São Paulo: Bain \& Company. Available online at: https://media.bain.com/Images/REPORT_Bain and Company Study of the potential for diversification of the Brazilian chemical industry.PDF / (accessed on 30 January 2021).

Bain \& Company. 2014. Potencial de diversificação da indústria química Brasileira - Relatório 2, Rio de Janeiro. Available online at: https:// www.bndes.gov.br/wps/wcm/connect/site/ec36c241-6b35-450ea42d-4004a03cf8c5/3 chamada publica FEPprospec0311 Quimicos Relatorio2.pdf?MOD=AJPERES\&CVID $=\mid z-F X H 8 \& C V I D=I z-$ FXH8\&CVID=IZ-FXH8\&CVID=Iz-FXH8\&CVID =Iz-FXH8\&CVID=IzFXH8\&CVID $=|z-F X H 8 \& C V I D=| z-F X H 8 \& C V I D=|z-F X H 8 \& C V I D=| z-F X H 8$ I (accessed on 30 June 2020).

Baltar C.A.M., Monte M.B.M., Andrade M.C., Moura R.L. 2001. Cloreto de potássio - CVRD / Mina de Taquari. In: Sampaio J.A., Luz A.B., Lins F.F. Usinas de beneficiamento de minérios do Brasil. Rio de Janeiro, CETEM/MCT, p. 61-74. Avaliable online at: http://mineralis.cetem. gov.br/bitstream/cetem/2037/1/usinas-de-beneficios-de-minerios-dobrasil Part1.pdf / (accessed on 20 January 2020).

Belarus. 2014. Business news. Available online at: https://www.belarus. by/en/business/business-news/belaruskali-starts-building-newmining-and-processing-factory i 14492.html / (accessed on 22 January 2020)

Belta. 2019. Belaruskali makes record high amount of fertilizers in 2018. Available online at: https://eng.belta.by/economics/view/belaruskalimakes-record-high-amount-of-fertilizers-in-2018-117808-2019/ (accessed on 22 January 2020).

BP. 2019. Statistical review of world energy 2018. 68th ed. London, BP Statistical Review of World Energy. Available online at: https://www. bp.com/content/dam/bp/business-sites/en/global/corporate/pdfs/ energy-economics/statistical-review/bp-stats-review-2019-full-report pdf / (accessed on 22 January 2020).

Brasil. Congresso Nacional (Senado). 1983. Anais do Senado. Diário do Congresso Nacional - 11/11/1983. Brasília, Editora do Congresso Nacional. Available online at: https://www.senado.leg.br/publicacoes/ anais/pdf-digitalizado/Anais Republica/1983/1983\%20Livro\%2015. pdf / (accessed on 14 July 2021).

Brasil. Congresso Nacional (Senado). 1985. Anais do Senado. Diário do Congresso Nacional - 06/03/1985. Brasília, Editora do Congresso Nacional. Available online at: https://www.senado.leg.br/publicacoes/ anais/pdf-digitalizado/Anais Republica/1985/1985\%20Livro\%201.pdf I (accessed on 14 July 2021)

Burney J.A., Davis S.J., Lobell D.B. 2010. Greenhouse gas mitigation by agricultural intensification. Proceedings of the National Academy of Sciences of the United States of America, 107(26), 12052-12057. https://doi.org/10.1073/pnas.0914216107.

Canadá. 2009a. Mosaic belle plaine expansion. Available online at: http://www.environment.gov.sk.ca/2008-101Environmental Impact Statement Executive Summary / (accessed on 9 July 2020).

Canadá. Saskatchewan Ministry of Environment. 2009b. Cory mine expansion PotashCorp. Available online at: http://environment.gov. sk.ca/2008-105 Technical Review Comments / (accessed on 22 January 2020)

Canadian-Mining. 2008. PCS adding 2.7 million tonnes per year. Available online at: www.canadianminingjournal.com/news/potash-expansion-pcsadding-2-7-million-tonnes-per-year/ / (accessed on 21 January 2020). 
CETEM. 2020 . Mineraldata from Ministry of Science and Technology (Brazil). Rio de Janeiro. Available online at: http://mineraldata.cetem. gov.br/mineraldata/app/ / (accessed on 21 January 2020).

Cocker M.D., Orris G.J., Dunlap P., Lipin B.R., Ludington S., Ryan R.J., Stowakiicz M., Spanski G.T., Wynn J., Yang C. 2017. Geology and undiscovered resource assessment of the potash-bearing Pripyat and Dnieper-Donets basins, Belarus and Ukraine. Scientific Investigations Report 2010-5090-BB, Virginia, USGS, 106p. Available online at: http://pubs.er.usgs.gov/publication/sir20105090BB / (accessed on 16 July 2021).

COMEXTAT. 2020. Statistics from the Brazilian Foreign Trade Secretary. Available online at: http://comexstat.mdic.gov.br/pt/home / (accessed on 28 July 2020).

CPDOC. 2020. Acervo FGV CPDOC - Petrobras. Available online at: http:// www.fgv.br/cpdoc/acervo/dicionarios/verbete-tematico/petrobras-1/ (accessed on 8 July 2020).

Craynon J.R. 1985. The mineral industry of France. Bureau of Mines / Minerals yearbook: Area reports: international 1985, 3, 305-326. Available online at https://digicoll.library.wisc.edu/cgi-bin/EcoNatRes/ EcoNatRes-idx?id=EcoNatRes.MinYB1985v3 / (accessed on 01 September 2020)

DNPM. 2015. Sumário Mineral 2014. Brasília, MME, 152p. Available online at: https://www.gov.br/anm/pt-br/centrais-de-conteudo/publicacoes/ serie-estatisticas-e-economia-mineral/sumario-mineral. I (accessed on 15 July 2021)

Exame. 2011. Vale testa nova tecnologia para extrair potássio em Sergipe. Available online at: https://exame.abril.com.br/negocios/valetesta-nova-tecnologia-para-extrair-potassio-em-sergipe/ / (accessed on 11 February 2020).

Farias P.I.V. 2015. Aspectos técnicos e econômicos da indústria de fertilizantes Npk no Brasil. MSc. Dissertation, Universidade Federa do Rio de Janeio, Rio de Janeiro, 172 p. Available online at: https:// rigeo.cprm.gov.br/handle/doc/14819 / (accessed on 15 July 2020).

Farias P.I.V., Freire E., Cunha A.L.C., Grumbach R.J.S., Antunes A.M.S 2020. The fertilizer industry in Brazil and the assurance of inputs for biofuels production: prospective scenarios after COVID-19. Sustainability, 12, 8889. https://doi.org/10.3390/su12218889

Forbes \& Manhattan. 2020. Brazil Potash Corp. Available online at: https://www.forbesmanhattan.com/portfolio/brazil-potash-corp/ (accessed on 16 January 2020).

Gazprom. 2018. PJSC Gazprom financial report 2018. Available online at: https://www.gazprom.com/investors/disclosure/reports/2018/ / (accessed on 17 January 2020).

Giles D. 2015. Mosaic announces \$1.7B potash expansion. Available online at: https://globalnews.ca/news/1872238/mosaic-announces-1 7b-potash-expansion/ / (accessed on 17 January 2020).

Globo. 2014. Buraco com 40 metros de largura surge em região de mina na Rússia. Available online at: http://g1.globo.com/mundo/ noticia/2014/11/buraco-com-40-metros-de-largura-surge-em-regiaode-mina-na-russia.html / (accessed on 14 July 2020).

Golder-Associates. 2015. Projeto Potássio Amazonas - Autazes: Estudo de Impacto Ambiental - EIA. Available online at: https://docplayer. com.br/6460923-Projeto-potassio-amazonas-autazes-estudo-deimpacto-ambiental-eia.html / (accessed on 20 July 2020).

Gomes M.A.F., Souza M.D., Boeira R.C., Toledo L.G. 2008. Nutrientes vegetais no meio ambiente: ciclos bioquímicos, fertilizantes e corretivos. 2nd ed. Documentos 66, Jaguariúna-SP, Embrapa Meio Ambiente, 61 p. Available online at: http://ainfo.cnptia.embrapa.br/ digital/bitstream/CNPMA/7718/1/documentos 66.pdf / (accessed on 2 August 2020)

Grumbach R.J.S., Franco F.L., Silva J.W., Grumbach R.P. 2020. Construindo o futuro: o método Grumbach de gestão estratégica. Timburi-SP, Cia do eBook, 273 p. Available online at: https://www.amazon.com.br/ Construindo-Futuro-M\%C3\%A9todo-Grumbach-Estrat\%C3\%A9gicaebook/dp/B08GYKMGRJ / (accessed on 16 July 2021).

Hijbeek R., Van Loon M., Van Ittersum M. K. 2019. Fertiliser use and soil carbon sequestration: opportunities and trade-offs. CCAFS Working Paper, 264. Wageningen, the Netherlands, CGIAR Research Program on Climate Change, Agriculture and Food Security (CCAFS). Available online at: https://ccafs.cgiar.org/resources/publications/fertiliser-use-and-soilcarbon-sequestration-trade-offs-and / (accessed on 13 July 2021).

IBRAM. 2015. Oficina técnica para debater a importância da exploração do potássio para a agricultura brasileira na Comissão de Agricultura, Pecuária, Abastecimento e Desenvolvimento Rural. Available online at: https://www2.camara.leg.br/atividade-legislativa/comissoes/comissoes- permanentes/capadr/audiencias-publicas/audiencias-publicas-2015/ mesa-tecnica-16-de-dezembro-ibram / (accessed on 14 July 2020).

ICIS. 2018. Global fertilizer trade map. Available online at: https://www. icis.com/explore/resources/global-fertilizer-trade-flow-map-2018 (accessed on 1 June 2018).

IFA .2020b. IFASTAT Comsumption report. Available online at: https:// www.ifastat.org/ / (accessed on 1 June 2020).

IFA. 2020a. Agenda 2030 - Plant nutrients and climate action. Available online at: https://www.fertilizer.org/Public/Stewardship/Publication Detail.aspx?SEQN=5854\&PUBKEY=F8D6C582-AA17-4A43-BF3143B36E10C236 / (accessed on 3 August 2020).

IFDC, UNIDO. 1998. Fertilizer manual. Dordrecht, Kluwer Academic Publishers, $618 \mathrm{p}$.

In The Mine. 2018. O engenheiro que trás a mineração da infância. In the Mine, 73, 22-26. Available online at: https://www.inthemine.com. br/site/o-engenheiro-que-traz-a-mineracao-da-infancia/ (accessed on 8 January 2020).

$\mathrm{K}+\mathrm{S}$. 2018. Annual report 2017. Available online at: https://www.kpluss. com/en-us/.pdf/investor-relations/2017/gb2017.pdf / (accessed on 17 September 2020)

$\mathrm{K}+$ S. 2019. Annual report 2018. Available online at: https://www.kpluss. com/en-us/.pdf/investor-relations/2018/gb2018.pdf / (accessed on 17 September 2020)

K+S. 2020. Our business. Available online at: https://www.ks-potashcanada. com/about-us/business / (accessed on 21 January 2020).

Lapido-Loureiro F.E., Melamed R.G., Figueiredo Neto J. 2008. Fertilizantes: agroindústria e sustentabilidade. Rio de Janeiro, CETEM, 655p. Available online at: http://mineralis.cetem.gov.br/ handle/cetem/497 / (accessed on 14 July 2021)

Lazenby H. 2017. PotashCorp completes Rocanville expansion. Available online at: https://www.miningweekly.com/article/potashcorp-completesrocanville-expansion-2017-10-13 / (accessed on 20 January 2020).

Loiko O. 2019. New potash capital in Petrikov. Belaruskali begins mining large deposit at own expense. Available online at: www.ctv.by/en/newpotash-capital-in-petrikov-belaruskali-begins-mining-large-depositat-own-expense / (accessed on 23 January 2020).

Marcial E.C., Grumbach R J.D.S. 2008. Cenários prospectivos: como construir um futuro melhor. Rio de Janeiro, FGV Editora, 228p.

Martino O. 1981. The mineral industry of Brasil. In: USGS. Minerals yearbook 1978-79: area reports: international. Washington, Government Printing Office. v.3, p. 167-190. Available online at: https://books.google.com.br/books?id=nbj7fdnxnGIC\&pg=PA167\&hl= pt-BR\&source $=\mathrm{gbs}$ toc $\mathrm{r} \& \mathrm{cad}=4 \mathrm{\#} \mathrm{v}=$ onepage $\& \mathrm{q} \& \mathrm{f}=$ false $/$ (accessed on 22 January 2021).

MDS. 2020. Mining data solutions. Available online at: https:// miningdataonline.com/ / (accessed on 14 July 2020).

MiceTimes. 2019. Potassium as a new economic driver Belarus. Available online at: https://web.archive.org/web/20200728230516/https:// micetimes.asia/potassium-as-a-new-economic-driver-belarus (accessed on 22 January 2020).

Mining. 2011. PotashCorp's Allan mine in expansion mode. Available online at: https://www.mining.com/potashcorps-allan-mine-inexpansion-mode/ / (accessed on 20 January 2020).

Mosaic. 2014. The Mosaic Company Form 10-K 2013. Available online at: https://s1.q4cdn.com/823038994/files/doc financials/2013/ar/88877f76a1c4-e0d2-99f1-6fa494470de5.pdf / (accessed on 10 July 2020).

Mosaic. 2015. The Mosaic Company Form 10-K 2014. Available online at: $\quad$ https://s1.q4cdn.com/823038994/files/doc financials/2014/ ar/926bd266-9218-2350-3224-c85208521bba.pdf / (accessed on 10 July 2020).

Mosaic. 2016. Mosaic fertilizantes adquire Vale Fertilizantes por US $\$ 2,5$ bilhões. Available online at: https://web.archive.org/ web/20200115231334/http://www.mosaicco.com.br/resources/3047. htm / (accessed on 14 March 2020).

Mosaic. 2017. The Mosaic Company Form 10-K 2016. Available online at: https://d18rn0p25nwr6d.cloudfront.net/CIK-0001285785/4e5baa30c4d8-4e6d-a1c2-ea83fa86f4b1.pdf / (accessed on 10 July 2020).

Mosaic. 2018. The Mosaic Company Form 10-K 2017. Available online at: https://d18rn0p25nwr6d.cloudfront.net/CIK-0001285785/c368796cd0c7-4303-bdbd-5c7332a8a8d1.pdf / (accessed on 10 July 2020).

Mosaic. 2019a. The Mosaic Company Form 10-K 2018. Available online at: https://d18rn0p25nwr6d.cloudfront.net/CIK-0001285785/7de928093c13-491e-a712-aff215a462b7.pdf / (accessed on 10 July 2020).

Mosaic. 2019b. 2018 Annual Sustainability disclosure \& GRI index. Available online at: https://mosaicco.com/fileLibrary/publicFiles/0- 
Mosaic-2018-Sustainability-Disclosure-and-GRI-Index-1.pdf (accessed on 10 July 2020)

Mosaic. 2019c. Annual Report 2018. Available online at: https://s1.q4cdn. com/823038994/files/doc financials/2018/ar/fba9f339-967e-2feb9781-43eb66f4c86d.pdf / (accessed on 10 July 2020)

MPF. 2019. Audiência define primeiras etapas para consulta ao povo indígena Mura sobre empreendimento em Autazes (AM). Available online at: http://www.mpf.mp.br/am/sala-de-imprensa/noticias-am/ mpf-audiencia-define-primeiras-etapas-para-consulta-ao-povoindigena-mura-sobre-empreendimento-em-autazes-am / (accessed on 13 July 2020).

Nakamura P. 2006. Petrobras venderá reservas gigantes de potássio no AM. Available online at: https://www2.senado.leg.br/bdsf/bitstream/handle/ id/457947/noticia.htm?sequence=1 / (accessed on 31 January 2020).

Nascimento M., Lapido-Loureiro F.E. 2004. Fertilizantes e sustentabilidade: o potássio na agricultura brasileira. Série Estudos e Documentos, 61. Rio de Janeiro, CETEM/MCT, 66 p. Available online at: http://mineralis.cetem.gov.br/bitstream/cetem/579/1/sed-61.pdf / (accessed on 2 July 2020).

Nickel R. 2013. Uralkali to delay potash expansion if BHP mine proceeds. Available online at: https://www.reuters.com/article/uralkali-bhp-potash/ update-2-uralkali-to-delay-potash-expansion-if-bhp-mine-proceedsidUSL2N0E314H20130522 / (accessed on 22 January 2020).

Nutrien. 2019a. Annual information form 2018. Available online at: https:// www.nutrien.com/sites/default/files/uploads/2019-02/2018\%20 Nutrien\%20Annual\%20Information\%20Form\%20.PDF / (accessed on 2 July 2020).

Nutrien. 2019b. 2018 Annual report. Available online at: https://www. nutrien.com/2018-annual-report / (accessed on 2 July 2020).

Nutrien. 2019c. Sustainability report 2018. Available online at: https:// www.nutrien.com/sustainability/reports / (accessed on 2 July 2020).

Petrobras. 2020. Formulário de referência 2019 - Petróleo Brasileiro SA. Versão 40. Available at: https://www.investidorpetrobras.com.br/ resultados-e-comunicados/relatorios-anuais// (accessed on 2 July 2020).

Porter M. 1998. Competitive strategy: techniques for analyzing industries and competitors. New York, Free Press, 436p.

PotashCorp. 2018. 2017 Annual report. Available online at: https:// www.nutrien.com/sites/default/files/uploads/2018-02/2017\%20 PotashCorp\%20Annual\%20Report.pdf / (accessed on 17 September 2020).

Potássio do Brasil. 2015a. A importância da exploração do potássio para a agricultura brasileira. Apresentação ao Senado Federal. Available online at: https://www2.camara.leg.br/atividade-legislativa/ comissoes/comissoes-permanentes/capadr/audiencias-publicas/ audiencias-publicas-2015/audiencia-publica-24-de-novembro-de2015-potassio-do-brasil / (accessed on 1 July 2020).

Potássio do Brasil. 2015b. Developing a world class potash basin investor presentation. Available online at: https://web.archive.org/ web/20150611160852/http://www.potassiodobrasil.com.br/index.php/ pagina/view/17/presentation / (accessed on 01 July 2016)

Potássio do Brasil. 2016. O potássio da Bacia do Amazonas : avanços na pesquisa e perspectivas. In: Simpósio Brasileiro de Exploração Mineral, 7 , p. 41. Available online at: https://docplayer.com.br/24305693O-potassio-da-bacia-do-amazonas-avancos-na-pesquisa-eperspectivas-simexmin-maio-2016.html / (accessed on 01 July 2017).

Potássio do Brasil. 2018. Extract, Nourish, Flourish. Available online at: https://potassiodobrasil.com.br/assets/pdf/201802-BPC-CorporatePresentation-Website.pdf / (accessed on 1 July 2020).
Reuters. 2020. Belaruskali to sign new potash supply deal with China in. Available online at: https://br.reuters.com/article/basicMaterialsSector/ idUSR4N29G00U / (accessed on 20 January 2020).

Rice G.S., Davis J. A. 1927. Potash Mining in Germany and France. Washington, Government Printing Office, 92 p. Available online at: https://digital.library.unt.edu/ark:/67531/metadc12453/m1/58/ / (accessed on 28 January 2021)

Russian News Agency. 2018. Russia and Belarus to decide on gas pricing from 2020. Available online at: https://tass.com/economy/1037878 / (accessed on 28 January 2020).

Sergipe (Estado). 2014. Projeto Carnalita: cadeia de fertilizantes em SE. Slides de Apresentação ao Senado Federal. Available online at: https://legis.senado.leg.br/comissoes/reuniao?reuniao=2316 / (accessed on 7 February 2020).

The Canadian Press. 2014. Agrium restarts Vanscoy potash mine after mechanical failure. Available online at: https://www. theglobeandmail.com/report-on-business/industry-news/energyand-resources/agrium-restarts-vanscoy-potash-mine-aftermechanical-failure-expansion/article22247002/ / (accessed on 22 January 2020)

United Nations. 2020. Goal 2: Zero Hunger. Available online at: https://www.un.org/sustainabledevelopment/hunger/ / (accessed on 31 July 2020).

Uralkali. 2011. Ust-Yayva project news. Available online at: https://www. uralkali.com/press center/project news/Ust-Yayva/item4048/?print=Y I (accessed on 21 January 2020)

Uralkali. 2016. Investing in the future. Available online at: https://www. uralkali.com/upload/iblock/744/AR-2015-eng.pdf / (accessed on 22 January 2020).

Uralkali. 2017. Integrated report 2016. Available online at: https://www. uralkali.com/investors/reporting and disclosure/ / (accessed on 22 January 2020).

Uralkali. 2019. Annual report 2018. Available online at: https://www. uralkali.com/upload/iblock/ec9/2928-uralkalii-godovoi-otchet-ang.pdf I (accessed on 22 January 2020).

USGS. 2019. U.S. Geological Survey, Mineral Commodity Summaries: Potash. Available online at: https://prd-wret.s3-us-west-2.amazonaws. com/assets/palladium/production/atoms/files/mcs-2019-potas.pdf / (accessed on 22 January 2021).

USGS. 2020. Mineral resources online spatial data. Available online at: https://mrdata.usgs.gov / (accessed on 23 February 2020).

Vale. 2017. Formulário 20-F para o exercício encerrado em 31 de dezembro de 2016. Rio de Janeiro. Available online at: http://www. vale.com/brasil/PT/investors/information-market/annual-reports/20f/ Paginas/default.aspx / (accessed on 31 July 2020).

Vale. 2019. Formulário 20-F para o exercício encerrado em 31 de dezembro de 2017. Rio de Janeiro. Available online at: http://www. vale.com/brasil/PT/investors/information-market/annual-reports/20f/ Paginas/default.aspx / (accessed on 31 July 2020).

Vorotnikov V. 2015. Investing in the future. Available online at: https://www.emj.com/features/uralkali-tapers-its-growth-strategy/ / (accessed on 21 January 2020).

Warren J.K. 2006. Evaporites: sediments, resources and hydrocarbons. Berlin, Springer. http://dx.doi.org/10.1007/3-540-32344-9

Woodroof N. 2019. Belarus expected to reduce potash output. Available online at: https://www.worldfertilizer.com/potash/06092019/ belarus-expected-to-reduce-potash-output / (accessed on 22 January 2020). 